\title{
PRAVO NA PRISTUP SUDU KAO ASPEKT PRAVA NA PRAVIČNO SUĐENJE
}

Dragan Elijaš, viši ustavnosudski savjetnik - mentor

Dr. sc. Sandra Marković, odvjetnica iz Zagreba

Sanja Trgovac, viši ustavnosudski savjetnik - mentor
UDK: 342.722

Ur.: 23. veljače 2016.

Pr.: 10. ožujka 2016.

Izvorni znanstveni rad

\section{Sažetak}

Tema rada je pravo na pristup sudu, kao aspekt prava na pravično suđenje, kojem Ustavni sud pruža zaštitu u ustavnosudskim postupcima pokrenutim ustavnim tužbama, kojima se osporavaju odluke sudova donesene u raznovrsnim sudskim postupcima. U radu se naglašava temeljni značaj konvencijske zaštite, a to je stvaranje $i$ primjenjivanje standarda zaštite ljudskih prava $u$ okviru pravnog prostora Europe te se, kroz stajališta Europskog suda za ljudska prava, koja je Ustavni sud Republike Hrvatske prihvatio i razradio kroz konkretne predmete. Ističe se značaj ustavnosudskog aktivizma za zaštitu ljudskih prava. te se nalašava stajalište da je svrha članka 29. Ustava odnosno članka 6. Konvnencije u osiguranju poštenog postupanja, a ne u provjeri ispravnosti ishoda postupka. Tu tezu autori dokazuju kroz ovaj rad. Temeljni interes ovog rada, pravo na pristup sudu, autori prepoznaju kao izuzetno važan aspekt ustavnog prava na pravično suđenje. U prvom dijelu rada pristupa se općenito pravu na pravično suđenje i njegovim aspektima, daje se pogled prakse Europskog suda za ljudska prava i njezin utjecaj na praksu Ustavnog suda u konkretnom aspektu te se navode stajališta drugih država. U nastavku rada detaljno se analiziraju stajališta Ustavnog suda Republike Hrvatske vezana uz pravo na pristup sudu $i$, posebno, tijek promjena stajališta u ovom području zaštite. Stajališta Ustavnog suda i traženje sadržaja prava na pristup sudu autori prikazuju i kroz apstraktnu i konkretnu nadležnost Ustavnog suda. Tumačenje sadržaja ustavnih prava, koje Ustavni sud daje kroz svoje odluke $i$ rješenja, autori smatraju najznačajnijim doprinosom razvoju ustavnog sudovanja u Republici Hrvatskoj.

Ključne riječi: Ustavni sud, pravično suđenje, pristup sudu, Europski sud za ljudska prava, Konvencija, Ustav. 


\section{1. $U$ VOD}

Ustavni sud Republike Hrvatske (u daljnjem tekstu: Ustavni sud) u svojim odlukama izrazitu pozornost poklanja zaštiti prava na pravično suđenje u ustavnosudskim postupcima pokrenutim ustavnim tužbama, kojima se osporavaju odluke sudova donesene u raznovrsnim sudskim postupcima (građanski, kazneni, upravni...). Kada se promatraju odluke Ustavnog suda donesene u povodu ustavnih tužbi u posljednjih nekoliko godina, zaključak bi mogao biti da se Ustavni sud gotovo isključivo bavi zaštitom prava na pravično suđenje, u svim njegovim aspektima. Rezultati takvog intenzivnog razmatranja eventualnih povreda ustavnog prava na pravično suđenje vidljivi su u novijoj praksi Ustavnog suda, u kojoj su standardi zaštite tog ustavnog prava ${ }^{1}$ podignuti na visoku razinu.

Pravo na pravično suđenje, zajamčeno člankom 29. Ustava Republike Hrvatske, ${ }^{2}$ u Konvenciji za zaštitu ljudskih prava i temeljnih sloboda (u daljnjem tekstu: Konvencija) jamči se člankom $6 .{ }^{3}$ Naglašavamo temeljni značaj konvencijske zaštite, a to je stvaranje i primjenjivanje standarda zaštite ljudskih prava u okviru pravnog prostora Europe. ${ }^{4}$ Obveza je nacionalnih sudova da prihvate, provode $\mathrm{i}$ djelotvorno štite dostignute europske pravne standarde, koji predstavljaju temelje zajedničke pravne kulture. Naime, nacionalni sudovi, uključujući i Ustavni sud, sporove moraju rješavati u skladu s pravnim europskim standardima, a u okviru nacionalnih pravnih propisa. ${ }^{5}$ Ustavni sud je u odluci U-III-5807/2010 ${ }^{6}$ podsjetio na tu obvezu: "I Ustavni sud u postupcima pokrenutim ustavnim tužbama ima zadaću osigurati da se nadležna tijela državne i javne vlasti pridržavaju svojih obveza osiguravanja ljudskih prava i temeljnih sloboda zajamčenih u Ustavu (članak 125. alineja 4.). Budući da je Republika Hrvatska kao suverena država prenijela dio svoje sudbene jurisdikcije na Europski sud, da se u postupcima

1 U praksi Ustavnog suda koristi se i pojam "ustavno jamstvo". Pojmovi "ustavno jamstvo" i "ustavno pravo" u teoriji i u praksi koriste se vrlo često kao sinonimi. Niti iz ustavnosudske prakse, niti iz odredaba Ustava nije moguće razgraničiti sadržaj ovih pojmova, što bi bilo značajno u ustavnom sudovanju. Novija tendencija Ustavnog suda je razgraničiti i definirati sadržaj ovih pojmova, u čemu će veliki doprinos imati rad na stvaranju kataloga ustavnih prava i sloboda. Povremeno se kao sinonimi koriste i pojmovi "ustavno jamstvo" i "ustavno načelo". O navedenim pojmovima i u Duško Vrban, Država i pravo, Zagreb, 2003., str. 181.

2 Ustav Republike Hrvatske, Narodne novine, broj 56/90, 135/97, 8/98 - pročišćeni tekst, 113/00, 124/00 - pročišćeni tekst, 28/01, 41/01 - pročišćeni tekst, 55/01 - ispr., 76/10, 85/10 pročišćeni tekst i $5 / 14$

3 Konvencija za zaštitu ljudskih prava i temeljnih sloboda, Narodne novine - Međunarodni ugovori, broj 18/97, 6/99 - pročišćeni tekst, 8/99 - ispr., 14/02 i 1/06.

4 Više u Jasna Omejec, Vijeće Europe i Europska unija, Institucionalni i pravni okvir, Novi informator, Zagreb 2008.

5 Polazeći od te temeljne postavke, Europski sud je već 1978. godine u presudi Irska protiv Ujedinjenog Kraljevstva, izrazio stajalište da "presude Suda zapravo služe ne samo da se riješe oni slučajevi koji su podneseni pred Sud, već, puno šire, da razlože, očuvaju i razviju pravila koja je ustanovila Konvencija."

6 Odluka broj: U-III-5807/2010 od 30. travnja 2013., Narodne novine, br. 57/13 i internetska stranica Ustavnog suda (u daljnjem tekstu: www.usud.hr). 
pokrenutim ustavnim tužbama pred Ustavnim sudom primjenjuju pravni standardi koje je u svojoj praksi izgradio Europski sud i da je odluka Ustavnog suda posljednja nacionalna odluka u tim postupcima protiv koje podnositelji imaju pravo podnošenja pojedinačnog zahtjeva Europskom sudu, Ustavni sud u provedbi svoga nadzora mora slijediti navedena pravila o ocjeni dokaza u postupku pred Europskim sudom. Slijedom toga, i tijela kaznenog progona te kazneni sudovi trebaju uzimati u obzir tu obvezu Ustavnog suda da slijedi pravila Europskog suda o ocjeni dokaza i u ustavnosudskim postupcima zaštite ustavnih prava.//7 Samo se na taj način osigurava izvršavanje međunarodnih obveza koje je Republika Hrvatska prihvatila ratifikacijom Konvencije. Time se, naime, omogućuje da se sporovi riješe na nacionalnoj razini izravnom primjenom Konvencije i prakse Europskog suda u skladu s načelom supsidijarnosti konvencijskog nadzornog sustava."

U ustavnom sudovanju Republike Hrvatske aktivizam u tumačenju sadržaja ustavnih prava i odredbi Ustava naročito je izražen u recentnoj praksi Ustavnog suda. O potrebi tumačenja propisa, a posebno Ustava, prof. Smerdel piše: "Tumačenje propisa racionalna je djelatnost kojom se utvrđuje značenje pravnih propisa. Tumačenje propisa nužno je za njihovu primjenu. "Samo savršene zakone ne treba tumačiti!", konstatirali su antički rimski pravnici. Međutim, savršeni zakoni ne postoje. Europski sud to je u odluci iz 1995. godine kazao sljedeće: Koliko god da je precizno formulirana zakonska odredba, u bilo kojem pravnom sustavu, uključujući i kazneno pravo, postoji neizbježan element sudskog tumačenja. Uvijek će postojati potreba za preciziranjem (elucidation) spornih točaka i za prilagođavanjem izmijenjenim okolnostima." Svaki zakon treba znati protumačiti kako bi ga se ispravno primijenilo.// Za ustavne odredbe, uslijed njihova načelnog značaja, to vrijedi bez iznimke. Bez stručnog tumačenja ustavi ostaju skupinama općenitih stipulacija. Kao takvi, ne mogu se izravno primjenjivati na konkretne situacije, pa čak ni na temeljna pitanja funkcioniranja sustava ustrojstva vlasti. Ustavna je interpretacija upravo zbog tog razloga u nas dugo vremena bila zanemarivana. (...)" $)^{n / 9}$

I kada analiziramo praksu njemačkog Saveznog ustavnog suda, koja je imala, i ima, značajan utjecaj na praksu Ustavnog suda Republike Hrvatske, naglašavamo riječi prof. Omejec, koja navodi: "Pristup ustavnom tekstu kao jedinstvenoj

7 // - oznaka za razdvajanje stavaka u citatima

8 Branko Smerdel, Ustavno uređenje europske Hrvatske, Narodne novine, Zagreb, lipanj 2013., str. 85. i 86.

9 Prof. Smerdel navodi: "Credo sudačkog aktivizma glasi: “Ako u zakonu postoji pravna praznina, ustavni sucu su je dužni popuniti pravnim shvaćanjem utemeljenim na njihovom razumijevanju ustavnih odredbi i načela". Teleološka metoda, kao najvažnija metoda interpretacije (J.Barbić), omogućava svakom službeniku koji primjenjuje zakon, pa i svakom onom na koga se zakon odnosi, da objektivno i u cijelosti procijeni usklađenost i unutarnju koherentnost zakonskih tekstova i očekivane socijalne učinke. Polazeći od cjeline ustavnog teksta i važećih izvora međunarodnog prava, kombinacijom s ostalim metodama interpretacije, moguće je u većini slučajeva izvesti tumačenje kojim će se nejasne ili nepotpune odredbe zakona prilagoditi ustavom utvrđenim ciljevima./Prije svega, zakonodavci se moraju vratiti ustavnim načelima.(...)"., op. cit., str. 90. i 91. 
smislenoj logičko-teleološkoj cjelini (“die Einheit dr Verfassung als eines logischteleologischen Sinngebildes"(BVerfGE 19, 206 (220); BVerfGE 30,1(19); BVerfGE 33,23 (29))", kao i stajalište Saveznog ustavnog suda da se odredbe Ustava uvijek moraju interpretirati tako da rezultat bude suglasan s osnovnim načelima Ustava, to jest $\mathrm{s}$ njegovim objektivnim poretkom vrijednosti utemeljenim na individualnim ustavnim pravima (BVerfGE 1, 14 (32); BVerfGE 7, 198 (205), danas ima čvrsto mjesto i u hrvatskoj ustavnosudskoj jurisprudenciji (...)"10

\section{PRAVIČNO SUĐENJE}

\subsection{Uvodno}

Pravo na pravično suđenje od 2000. godine jamči se u svim sudskim postupcima. Ustavni sud je ovo ustavno pravo u počecima razvoja određivanja sadržaja ustavnih prava štitio u skladu s tadašnjom odredbom članka 29. Ustava, dakle, kroz ustavnosudsku ocjenu o povredi prava na suđenje o kaznenoj odgovornosti. Promjenom članka 29. Ustava te približavanjem ustavnosudske prakse stajalištima Europskog suda za ljudska prava (u daljnjem tekstu: ESLJP) i ovo se ustavno pravo, s ustavnosudskog aspekta, jamčilo i u drugim sudskim postupcima, pogotovo u ocjeni eventualne povrede prava na suđenje o pravima građanske naravi. ${ }^{11}$ Pravo na pravično suđenje, zajamčeno člankom 29. Ustava, u Konvenciji jamči se člankom 6. (,pošteno suđenje”). ${ }^{12 / 13}$ Sadržaj ustavnog prava na pravično suđenje ograničen je na jamstva pravičnog suđenja pa Ustavni sud, ocjenjujući navode ustavne tužbe sa stajališta tog ustavnog prava, ispituje eventualno postojanje povreda u postupcima pred sudovima te na temelju toga, sagledavajući postupak kao jedinstvenu cjelinu, ocjenjuje je li postupak bio vođen na način koji je podnositelju osiguravao pravično suđenje. Ustavni sud u konkretnim postupcima ocjenjuje je li dokazni postupak proveden sukladno mjerodavnim postupovnim odredbama, je li podnositelju bilo omogućeno pratiti postupak, sudjelovati u njemu uz stručnu pomoć, je li bio u mogućnosti poduzimati sve zakonom dopuštene postupovne radnje i ulagati pravne lijekove, jesu li osporene presude valjano obrazložene

10 Jasna Omejec, Predgovor, Jurisprudencija njemačkog Saveznog ustavnog suda i hrvatsko ustavno sudstvo, u: Izbor odluka Ustavnog suda Savezne Republike Njemačke, ur.: Tobias Zern i Martin Bauch, Konrad Sdenauer Stifung, Zagreb, 2015., str. 19

11 Više u: Sandra Marković, Povreda ustavnog prava na pravično suđenje, Informator, br. 6115 od 13. listopada 2012. na str. 1., kao i u: Sandra Marković, Zaštita od arbitrarnosti u postupanju sudova i drugih državnih tijela kao aspekt prava na pravično suđenje, Godišnjak 22, Organizator, Zagreb, 2015., str. 1.

12 O značaju i dosegu članka 6. Konvencije i njegovoj primjeni u hrvatskoj praksi više u: Alan Uzelac, Hrvatsko procesno pravo i jamstvo pravičnog postupka iz Europske konvencije o zaštiti ljudskih prava, Zbornik Pravnog fakulteta Sveučilišta u Rijeci, Supplement: Spomenica prof. dr. Đuri Vukoviću, 1998., str. 1005-1030.

13 Engleski "fair trial", u Ustavu je: "pravično suđenje”, a u službenom prijevodu Konvencije: "pošteno suđenje". U ovom radu koristimo termin "pravično suđenje" 
i donesene sukladno mjerodavnim odredbama postupovnog prava i dr. ${ }^{14}$ Prof. Uzelac u razmatranju opsega primjene članka 6. Konvencije navodi da je ESLJP još od slučajeva Ringeisen i König zauzeo stajalište da je bitan sadržaj o kojem se odlučuje, a ne vrsta postupka u kojem se o njima odlučuje, tako da se načelno može preispitivati suđenje u svim vrstama postupaka, od kaznenog i stegovnog, preko parničnog i upravnog postupka, pa i postupaka pred drugim tijelima s javnim ovlastima. Bitno je, kako ističe Uzelac, da se u tim postupcima odlučuje o pravima i obvezama privatnog prava, što obuhvaća kako imovinska pitanja, tako i statusne, radne ili trgovačke stvari. Postupno, i razlikovanje između prava privatnopravne i javnopravne naravi prestalo je biti odlučujuće, jer je u svojoj jurisprudenciji ESLJP sve više potonjih predmeta podvodio pod jamstva iz članka $6 .{ }^{15}$ Smatramo bitnim za ovaj rad istaknuti riječi prof. Uzelca koji navodi: "Svrha zaštite koju pruža čl. 6. st. 1. Konvencije jest u osiguranju poštenog postupanja, a ne u provjeri ispravnosti ishoda postupka - odluke u konkretnom slučaju."

\subsection{Aspekti poštenog/pravičnog suđenja}

I u razmatranju aspekata članka 6. Konvencije izdvajamo riječi prof. Uzelca koji navodi: "Pravo na pošteno suđenje u praksi Europskog suda za ljudska prava razvijalo se i širilo postupno. Prema današnjem stanju prakse Suda u Strasbourgu, a uzimajući u obzir sistematiku iz suvremenih komentara i doktrinarnih tumačenja Konvencije (...), mogu se navesti sljedeći elementi ili aspekti prava na pošteno (pravično, fair) suđenje: - pravo na pristup sudu (access to court), - pravo na pravnu pomoć (legal aid and advice), - pravo na procesnu ravnopravnost (equality of arms, "jednakost oružja"); - pravo na javno i kontradiktorno suđenje (public hearing); - pravo na saslušanje (fair hearing); - pravo na dokaz (rights to proof); - pravo na javnu objavu presuda (public pronouncement of judgments); - pravo na sud ustanovljen zakonom (tribunal established by law); - pravo na neovisnost i nepristranost $u$ suđenju (impartiality and independence); - pravo na suđenje $u$ razumnom roku (reasonable time); - pravo na učinkovitu ovrhu presuda (effective enforcement); - zabrana arbitrarnog postupanja (arbitrariness) i pravo na pravnu sigurnost (legal certainty)." ${ }^{17}$ Sva navedena prava, kako to navodi Omejec, dijele se na "ona izrijekom navedena u članku 6. Konvencije i ona koja u njemu nisu izrijekom spomenuta, ali su implicitno sadržana ili su im inherentna, pa ih Europski sud izvodi iz članka 6. Konvencije u svojoj praksi (tzv. implicirana prava).(...)

14 Usp. odluke Ustavnog suda broj: U-III-1563/2002, U-III-1635/2003, U-III-2963/2004, U-III-1350/2005, U-III-1978/2006, U-III-4396/2007, U-III-3857/2008 i dr. (Izvor: odluka Ustavnog suda, broj U-III-459/2012 od 3. srpnja 2014., www.usud.hr).

15 Usp. Alan Uzelac, Pravo na pošteno suđenje: opći i građanski aspekti čl. 6. st. 1. Europske konvencije za zaštitu ljudskih prava i temeljnih sloboda, u: Usklađenost zakonodavstva i prakse sa standardima Europske konvencije za zaštitu ljudskih prava i temeljnih sloboda, ur. Ivana Radačić, str. 91.

16 Alan Uzelac, Pravo na pošteno suđenje:..., op. cit., str. 90.

17 Alan Uzelac, Pravo na pošteno suđenje:..., ibid 
Tipična implicirana prava koja su izvedena iz članka 6. Konvencije u Uzelčevu su popisu navedena pod točkama a., c., k., 1. (pravo na pristup sudu, pravo na procesnu ravnopravnost, pravo na učinkovitu ovrhu presude, zabrana arbitrarnog postupanja i pravo na pravnu sigurnost) i dijelu točke d. o kontradiktornom suđenju. Vitkauskas i Dikov u implicirana prava koja su primjenjiva i na građansku i na kaznenu glavu članka 6. Konvencije ubrajaju još i: - pravo na obrazloženu odluku. ${ }^{18}$

Iz teorije, samog sadržaja članka 29. Ustava, kao i iz prakse Ustavnog suda, proizlaze aspekti članka 29. stavka 1. Ustava. To su: pravo na jednakost oružja, pravo na sud/pravo na pristup sudu, pravo na kontradiktornost, pravo na javnu objavu presude, zabrana arbitrarnog postupanja, pravo na obrazloženu odluku, nepristranost suda, razumni rok, načelo vladavine prava te načelo pravne sigurnosti. ${ }^{19}$

\subsection{Komparativni prikaz}

Arsen Bačić navodi: "Američki koncept due process of law kompleksni je postupak obrane ljudskih prava koji u svome sadržaju krije svekoliki arsenal pravnih sredstava, (...)./ Upravo je američko iskustvo pokazalo da klauzula služi kao ograničenje koliko legislature toliko i egzekutive i sudbene vlasti. Klauzula o zakonitom postupanju u sudbenim postupcima, prema stajalištu Vrhovnog suda SAD iz slučaja Pennoyer v. Neff (1877), prije svega je insistirala na tome da sudionici spora imaju pravo koristiti se svim beneficijama poštenog suđenja te da se njihova prava ne mjere zakonskim propisima koji bi se na njih odnosili individualno, već se moraju procjenjivati temeljem općih odredaba koje se na njih primjenjuju u svim okolnostima. Sudske procedure doduše mogu varirati s obzirom na okolnosti, no sve će biti zasnovane na zakonu (due process) tek onda budu li slijedile uspostavljene norme prava, ili budu li - adaptirajući stare forme na nove probleme - čuvale načela slobode i pravde." ${ }^{20}$

Pretražujući praksu vezanu uz pravo na pravično suđenje navodimo i razmatranja vezana uz stajališta Ustavnog suda Republike Slovenije. Dajući primjere za predmete koji su u praksi Ustavnog suda Republike Slovenije, u okviru apstraktne kontrole, povezani s pravom na pošteno suđenje, zajamčeno člankom 6. Konvencije, Arne Marjan Mavčić izdvaja odluke br. U-I-27/95 od 24. listopada

18 Vidi: Jasna Omejec, Konvencija za zaštitu ljudskih prava i temeljnih sloboda u praksi Europskog suda za ljudska prava, strasbourški acquis, 2. dopunjeno izd., Novi informator, Zagreb, 2014., str. 1125.

19 Više u: Sandra Marković, Marijana Radin, Sanja Otočan i Sanja Trgovac, Katalog osobnih i političkih sloboda i prava, radni materijal u okviru projekta 60. godišnjica zaštite ljudskih prava u Europi, voditeljica projekta prof. dr.sc. Jasna Omejec, predsjednica Ustavnog suda Republike Hrvatske, Zagreb, 20. svibnja 2010.// Izvor: Arhiv USRH (neobjavljeno).

20 Arsen Bačić, Pravično suđenje i razumni rok kao garancije ustavnih prava i sloboda, u: Pravo na pošteno suđenje i razuman rok, pravo azila, ur. Jadranko Crnić i Nikola Filipović, Organizator, Zagreb, 2003., str. 10. i 11. 
1996., U-I-289/95 od 4. prosinca 1997. itd. ${ }^{21 / 22}$ Zanimljivo je navesti i riječi mr. sc. Boštjana Tratara, koji piše o praksi i stajalištima Ustavnog suda Republike Slovenije: "Ustavna prava, kod kojih već iz teksta ustavnih odredbi proizlazi, da ne mogu imati učinak protiv pojedinaca, su one koje pojedincima osiguravaju prava u kaznenim i drugim postupcima (npr. jamstava kod određivanja pritvora - članak 20., jednaka sigurnost prava u postupcima pred sudom i drugim državnim organima članak 22., pravo na sudsku sigurnost - članak 23., javna suđenja - članak 24., pravo na pravno sredstvo - članak 25., načelo zakonitosti u kaznenom pravu - članak 28., pravna jamstva u kaznenom postupku - članak 29., zabrana ponovnog suđenja za istu stvar - članak 31., pravo na korištenje svog jezika i pisma u postupcima pred državnim i drugim organima - članak 62., itd.). Kod ove skupine ustavnih prava je adresat više ili manje izričito određen - za njega su neposredno vezani državni i drugi organi te nosioci javnih ovlaštenja. Ta ustavna prava zbog toga očito ne uspostavljaju nikakve neposredne dužnosti do privatnih osoba. Za takve slučajeve Nerad navodi, da ima pojedinac i ovdje najmanje dužnost opustiti sva djela s kojima bi mogao posezati u takva prava (npr. nitko ne smije drugom spriječiti, da koristi svoje pravo na pravno sredstvo). ${ }^{.23}$

Ustav Bosne i Hercegovine u članku II/3e propisuje "pravo na pravično suđenje, odnosno pravo na pravično saslušanje u građanskim i krivičnim stvarima i druga prava vezana za krivični postupak". ${ }^{4}$ Pregledom prakse Ustavnog suda

21 Vidi: Doc. dr. sc. Arne Marjan Mavčić, The Influence of the European Court on Human Rights Case-Law on Slovenian Constitutional Case-Law (The Right to Fair trial)" ("Utjecaj pravorijeka Europskog suda za ljudska prava na pravorijek ustavnog suda Republike Slovenije (pravo na pravični postupak)), u Pravo na pošteno suđenje i razuman rok, pravo azila, op.cit., str. 144. i dr.

22 Navodeći i odluke koje se odnose na pojedinačnu kontrolu, Mavčić također naglašava značaj interpretacije te navodi: "The new Constitutional of the Republic of Slovenia of 1991., along with the catalogue of classic fundamental rights in combination with the newly defined powers of the Constitutional Court, established the foundation for the intensification of its role in this domain. It is considered that the Constitutional Court now has sufficient scope for such activity. The Slovenian Constitution contains adequate definitions of rights which allow for reasonably clear understanding. Almost all fundamental rights have the nature of legal principles and as such are still open to such an extent that they require significant further concretisation and expert interpretation (cit. from Pavčnik, Marijan,(...), also with the help of the provisions of the Convention and/or the practice of the European Court of Human Rights.", op. cit., str. 159.

23 Mr. sc. Boštjan Tratar (samostalni savjetnik Ustavnog suda Republike Slovenije): Pojedinci kao novi adresati ustavnih prava, u Zborniku radova Pravnog fakulteta u Splitu, god. 44, 3-4/2007., str. 543.-556, na str. 549.

24 U "Ljudskim pravima u Bosni i Hercegovini 2008", pravo, praksa i međunarodni standardi ljudskih prava sa ispitivanjem javnog mnijenja, Centar za ljudska prava Univerziteta u Sarajevu, 2009., str. 164. navodi se: "Što se tiče same pravičnosti sudskog postupka, ona uključuje više procesnih garancija od kojih se mogu istaći pravo na pristup sudu, usmenost i kontradiktornost rasprave i donošenja odluke u razumnom roku. Pravo na pristup sudu nije izričito predviđeno Evropskom konvencijom za zaštitu ljudskih prava i osnovnih sloboda, ali je ono ugrađeno u odredbe koje garantuju pravo na pravično suđenje. (...). Međutim, nije dovoljno da se pravo na pristup sudu samo proklamuje. Tako, ako je pomoć advokata 
Bosne i Hercegovine, ${ }^{25}$ u okviru članka 6. Konvencije, pod aspektom pristupa sudu izdvajamo odluku (koja se odnosila na upravni postupak), broj: U 7/00 od 18. i 19. kolovoza 2000 godine $^{26}$, u kojoj se navodi: "Odbijajući nadležnost da preispita činjenično stanje, Vrhovni sud Republike Srpske povrijedio je apelanticiono pravo na pristup sudu pune jurisdikcije zajamčeno Evropskom konvencijom za zaštitu ljudskih prava i osnovnih sloboda i Ustavom BiH." Također navodimo stajalište istog Suda: "U situaciji kada Vrhovni sud tri puta vraća predmet upravnim organima na ponovno rješavanje, zbog čega apelant nije bio u prilici da dođe do odluke suda o meritumu njegovih građanskih prava, apelantu nije pružen efektivan pristup sudu zajamčen članom 6. stavkom 1. Evropske konvencije." ${ }^{27}$ Nadalje, Ustavni sud Bosne i Hercegovine u odluci broj U 24/00 od 31. kolovoza 2001. ${ }^{28}$ navodi: "Član 6. stav 1. Evropske konvencije osigurava pravo na pristup sudu pune nadležnosti, kao i pravo da sud donese odluku u meritumu radi odlučenja o zahtjevu za povrat nezakonito oduzetog stana, čak i u slučaju kada je odgovarajući upravni postupak u toku." U odluci Ustavnog suda BiH iz 2003. godine navodi se: "Ustavni sud zapaža da je, time što nije riješeno o meritumu apelantičine tužbe, Općinski sud uskratio apelantici pravo na pristup sudu i time povrijedio član II/3.e Ustava Bosne i Hercegovine i član 6. stav 1. Evropske konvencije. Dalje, ova povreda nije ispravljena ni nakon podnošenja žalbe Kantonalnom sudu i izjavljene revizije Vrhovnom sudu." ${ }^{29}$ Zanimljiv je i primjer iz odluke broj AP 219/03 od 23. srpnja 2004. godine: "S obzirom na restriktivno tumačenje člana 187. Zakona o parničnom postupku, kojim je regulirano pravo na podnošenje tužbe za utvrđenje, došlo je do povrede apelantovog prava na pristup sudu iz člana II/3.e) Ustava Bosne i Hercegovine i člana 6. stava 1. Evropske konvencije." ${ }^{30}$ Izdvajamo i stajalište: "Ne postoji povreda prava na pristup sudu u slučaju kada apelant tužbom u upravnom sporu nije zahtijevao od suda da se održi usmena rasprava, a sud osporenu odluku donese u sjednici vijeća." ${ }^{\prime 1}$

neophodna kako bi se pristup sudu zaista i omogućio, država je dužna da je obezbijedi. (...) Još jedan problem predstavlja imunitet pojedinih lica koji ponekad može dovesti do kršenja prava na pristup sudu.(...)".

25 Vidi: Pregled prakse Ustavnog suda Bosne i Hercegovine, Sarajevo, 2009., str. 48. i dr. / Pregled prakse Ustavnog suda Bosne i Hercegovine, Pravosuđe.ba, Centar za sudsku dokumentaciju, pregledano 17. prosinca 2015.

26 Odluka je objavljena u Službenom glasniku Bosne i Hercegovine br. 6/01

27 Odluka Ustavnog suda Bosne i Hercegovine, broj U 15/00 od 15. i 16. prosinca 2000., objavljena je u Službenom glasniku Bosne i Hercegovine, broj 6/01.

28 Odluka je objavljena u Službenom glasniku Bosne i Hercegovine, br. 1/02.

29 Odluka Ustavnog suda BiH broj U 28/00 od 28. studenog 2003., objavljena je u Službenom glasniku $\mathrm{BiH}$, br. $8 / 04$

30 Odluka je objavljena u Službenom glasniku BiH br. 48/04.

31 Odluka o dopustivosti i meritumu broj AP 85/06 od 15. veljače 2006., objavljena je u Službenom glasniku BiH, br. 38/07. 


\section{STAJALIŠTA EUROPSKOG SUDA ZA LJUDSKA PRAVA}

\subsection{Povreda prava na pristup sudu uzrokovana intervencijom zakonodavca u postupak u tijeku}

Već je navedeno da stajališta ESLJP-a općenito, pa tako i o pravu na pristup sudu, bitno utječu na praksu Ustavnog suda. Pravo na pristup sudu u svjetlu stajališta ESLJP-a Ustavni sud počeo je sagledavati najprije u predmetima vezanim uz razumni rok u kojima su parnični postupci radi naknade štete protiv države prekinuti na temelju Zakona o izmjenama i dopunama Zakona o obveznim odnosima ${ }^{32}$ ili Zakona o dopunama Zakona o obveznim odnosima. ${ }^{33}$ Bila je riječ o parnicama pokrenutim zbog štete uzrokovane terorističkim aktom odnosno koju su uzrokovali pripadnici oružanih i redarstvenih snaga. U tim zakonima bilo je navedeno da se započeti postupci prekidaju, a nastavit će se nakon što se donese poseban propis kojim će se urediti odgovornost države za štetu nastalu uslijed terorističkih akata odnosno uzrokovanu od strane pripadnika hrvatskih oružanih i redarstvenih snaga. Naime, ESLJP je u presudi Kutić protiv Hrvatske, od 1. ožujka 2002..$^{34}$ utvrdio da "dugo razdoblje tijekom kojega je podnositeljima zahtjeva slijedom zakonodavnih mjera onemogućeno rješavanje njihovih građanskih tužbi u postupku pred domaćim sudovima" predstavlja povredu prava na pristup sudu. ESLJP je u toj presudi naveo: "Sud ponavlja da postupovna jamstva predviđena člankom 6. svakome daju pravo da sudu ili sudištu podnese bilo kakvu tužbu vezanu uz njegova građanska prava i obveze. Shodno tome, ovaj članak sadrži "pravo na sud", pri čemu pravo na pristup, to jest, pravo na pokretanje sudskih postupaka u građanskim predmetima, predstavlja jedan od vidova istog (vidi presudu u predmetu Golder protiv Ujedinjenog Kraljevstva od 21. veljače 1975., Serija A, br. 18, str. 13.-18., st. 28.-36.).// Nadalje, Sud smatra da pravo na pristup sudu također štiti provedbu konačnih, obvezujućih sudskih odluka, koje - u državama koji prihvaćaju vladavinu prava - ne mogu ostati nedjelotvorne na štetu jedne od stranaka (vidi presudu u predmetu Hornsby protiv Grčke od 19. ožujka 1997., Reports of Judgements and Decisions 1997- II. str. 510, st. 40.).// Sud primjećuje da su podnositelji zahtjeva u ovom predmetu imali mogućnost pokretanja pravnog postupka te da su je iskoristili kada su Općinskom sudu u Zagrebu podnijeli tužbu protiv države za naknadu štete u vezi s njihovom uništenom imovinom.// Time samim po sebi nisu ispunjeni svi zahtjevi postavljeni člankom 6. stavak 1. Konvencije. Valja također utvrditi je li stupanj pristupa predviđen odredbama domaćih zakona dovoljan da bi se osiguralo pojedinčevo "pravo na sud", a s obzirom na načelo vladavine prava u demokratskom društvu (vidi presudu u predmetu Ashingdane protiv Ujedinjenog Kraljevstva od 28. svibnja 1985., Serija A, br. 93, str. 24-25, st. 57). // Sud podsjeća da svrha Konvencije nije zajamčiti prava koja su teoretska ili prividna, već prava koja su praktična i

32 Zakon o izmjenama i dopunama Zakona o obveznim odnosima, Narodne novine, br. 7/96.

33 Zakon o dopunama Zakona o obveznim odnosima, Narodne novine, br. 112/99.

34 Zahtjev broj 48778/99. 
djelotvorna (vidi, mutatis mutandis, presudu u predmetu Airey protiv Irske od 9. listopada 1979., Serija A, br. 32, str. 12-14, st. 24 i predmetu Garcia Manibardo protiv Španjolske, br. 38695/97 od 15. veljače 2000., st. 43., neobjavljena).// U vezi s time, Sud ponavlja da se člankom 6. stavak 1. Konvencije jamči pravo pristupa sudu radi rješavanja građanskih sporova. Sud smatra da ovo pravo pristupa sudu ne obuhvaća samo pravo pokretanja postupka, već i pravo na "rješavanje" spora od strane suda. Bilo bi iluzorno kada bi pravni sustav države ugovornice pojedincu omogućavao podnošenje građanske tužbe sudu, a da mu pritom ne jamči rješavanje predmeta donošenjem konačne odluke u sudskom postupku. Isto tako, bilo bi nezamislivo da članak 6. stavak 1. sadrži podroban opis postupovnih jamstava koja se pružaju strankama u parnici - tj. jamstva pravičnog, javnog i brzog postupka bez da ime jamči konačno rješavanje njihovih građanskih sporova (vidi, mutatis mutandis, gore navedenu presudu u predmetu Hornsby v. Greece, str. 510, st. 40.)." ESLJP je u predmetu Kutić zaključno ocijenio: "Međutim, u predmetnom slučaju, prekid postupaka traje već više od šest godina, od čega je više od četiri godine proteklo otkako je Konvencija stupila na snagu u odnosu na Hrvatsku, pri čemu u međuvremenu nije donesen nikakav novi propis kojim bi se podnositeljima zahtjeva omogućilo rješavanje njihovih građanskih tužbi.// U tim okolnostima, Sud ne može prihvatiti da je stupanj pristupa predviđen odredbama domaćih zakona dovoljan da bi se podnositeljima zahtjeva osiguralo "pravo na sud"(...)."

U presudi Multiplex protiv Hrvatske od 10. srpnja 2003. ${ }^{35}$ ESLJP je, ponovivši stajalište zauzeto u predmetu Kutić, ocijenio: "Sud uviđa kako situacija u kojoj je podnesen značajan broj pravnih tužbi protiv države u kojima se traže veliki iznosi novca može tražiti neko dodatno uređenje od strane države i da u tom smislu države uživaju određenu slobodu procjene. No, poduzete mjere ipak moraju biti u skladu s člankom 6. stavkom 1. Konvencije.// U ovom je predmetu postupak do sada prekinut više od tri godine i sedam mjeseci i u međuvremenu nije donesen nikakav novi zakon koji bi omogućio tvrtki podnositelju zahtjeva da se odluči o njenom zahtjevu građanske naravi.//U takvim okolnostima Sud ne može prihvatiti da je stupanj pristupa koji je osiguran prema nacionalnom zakonodavstvu bio dovoljan da se osigura pravo tvrtke- podnositelja zahtjeva na "prvo na sud".//Sud stoga utvrđuje da dugo razdoblje tijekom kojeg je tvrtki podnositelju zahtjeva bilo onemogućeno da se o njenom zahtjevu građanske naravi odluče domaći sudovi kao posljedica zakonodavne mjere predstavlja povredu članka 6. stavka 1. Konvencije." 


\subsubsection{Promjena prakse Ustavnog suda}

Nakon navedene dvije presude ESLJP-a, ${ }^{36}$ Ustavni sud je također počeo ocjenjivati, u predmetima vezanim uz razumni rok, je li uz povredu prava na suđenje u razumnom roku, i zakonom određen prekid postupka utjecao na povredu prava na pristup sudu. U tom smislu je i promijenio svoju praksu, izrijekom utvrdivši (i) povredu prava na pristup sudu. U odluci broj U-IIIA-829/2002 od 24. travnja 2004. ${ }^{37}$ Ustavni sud je naveo: "Vodeći računa o svim ovim okolnostima te o činjenici da je zakonom određen prekid sudskog postupka radi naknade štete prouzročenih terorističkim aktima i javnim demonstracijama trajao sedam (7) godina, pet (5) mjeseci i dvadeset pet (25) dana te da je prekid obuhvatio cjelokupno pravno relevantno razdoblje od stupanja na snagu Europske konvencije do podnošenja ustavne tužbe u trajanju od četiri (4) godine, pet (5) mjeseci i dvanaest (12) dana, Ustavni sud utvrđuje da je takvim zakonom određenim prekidom postupka povrijeđeno člankom 29. stavkom. 1. Ustava zajamčeno pravo podnositelja da zakonom ustanovljeni neovisni i nepristrani sud u razumnom roku odluči o njegovim pravima i obvezama. Takvim zakonom određenim prekidom postupka u ovom je slučaju podnositelju povrijeđeno i pravo na pristup sudu, koji je dio prava na sud, također zajamčenog odredbom članka 29. stavka 1. Ustava o temeljnom ljudskom pravu na pravično suđenje.”

\subsubsection{Utvrđenje povrede prava na pristup sudu od strane ESLJP-a (i nakon promjene prakse Ustavnog suda)}

Navedena odluka Ustavnog suda, međutim, nije prošla test u ESLJP-u. U presudi Novaković protiv Hrvatske od 12. travnja 2007. ${ }^{38}$ ESLJP je ocijenio da se podnositelj, unatoč usvajajućoj odluci Ustavnog suda, u kojoj je utvrđena povreda i prava na suđenje u razumnom roku i prava na pristup sudu, i dalje može smatrati žrtvom povrede prava na pristup sudu i to zbog preniskog iznosa pravične naknade. Ustavni sud je, naime, tek početkom 2005. godine znatno povisio iznos naknade koju dodjeljuje u slučaju utvrđenja, uz povredu na suđenje u razumnom roku, i povrede prava na pristup sudu. ESLJP je naveo: "Sud podsjeća da je u predmetu Tomašić (vidi predmet Tomašić protiv Hrvatske, br. 21753/02, stavci 26.-36., 19. listopada 2006.) utvrdio da je iznos naknade, koji je bio $15 \%$ od onoga što Sud općenito dosuđuje u sličnim hrvatskim predmetima, bio očigledno nerazuman.

36 Vidi i druge presude koje se odnose na povredu prava na pristup sudu u istoj stvari, primjerice Pikić protiv Hrvatske od 18. siječnja 2005. (zahtjev br. 16552/02), Urukalo i Nemet protiv Hrvatske od 28. travnja 2005. (zahtjev br. 26886/02), Subašić protiv Hrvatske od 1. prosinca 2005. (zahtjev br. 18322/03), Krivokuća protiv Hrvatske od 23. ožujka 2006. (zahtjev br. 38770/02), Hajduković protiv Hrvatske od 12. travnja 2007. (zahtjev br. 38303/02), Milašinović protiv Hrvatske od 24. svibnja 2007. (zahtjev br. 41751/02) i dr.

37 Odluka je objavljena u Narodnim novinama, br. 44/04 i na www.usud.hr. Dvoje sudaca protivilo se izreci i obrazloženju te su izradili zasebna izdvojena mišljenja.

38 Zahtjev br. 43446/02 
Budući da je podnositelj zahtjeva u ovome predmetu primio isti iznos, Sud primjećuje da se njegova situacija ni na koji način ne razlikuje od predmeta Tomašić i ne nalazi razloga odstupiti od svojega zaključka do kojega je došao u tom predmetu. Stoga podnositelj zahtjeva još uvijek može tvrditi da je „žrtva“ povrede svoga prava na pristup sudu, te Vladin prigovor treba dakle odbiti.(...) // Sud je često utvrđivao povrede prava podnositelja zahtjeva na pristup sudu na temelju članka 6 . stavka 1. Konvencije u predmetima u kojima su se postavljala pitanja slična pitanju iz ovoga predmeta (vidi, na primjer, naprijed citirani predmet Kutić protiv Hrvatske, i predmet Multiplex protiv Hrvaske, br. 58112/00, 10. srpanj 2003.).// Nakon što je ispitao sve podnesene mu materijale, Sud smatra da Vlada nije iznijela niti jednu činjenicu ili argument koji bi ga mogli navesti na donošenje drukčijeg zaključka u ovome predmetu.// Stoga je došlo do povrede članka 6. stavka 1."

Postoji međutim i odluka o dopuštenosti, u predmetu Majdandžić protiv Hrvatske od 1. veljače 2007., u kojoj je ESLJP utvrdio da podnositeljima nije povrijeđeno ni pravo na pristup sudu ni pravo na suđenje u razumnom roku, jer je odluka Ustavnog suda protiv koje je zahtjev bio podnesen donesena u skladu s praksom ESLJP-a. ${ }^{39}$ Podnositeljima je Ustavni sud, prema ocjeni ESLJP-a, dosudio i primjerenu naknadu (po mjerilima iz 2005.) te oni više nisu imali status žrtve povrede navedenih prava. ${ }^{40}$

\subsection{Još o pristupu sudu kroz presude ESLJP-a}

S obzirom na bogatu praksu i u odnosu na Republiku Hrvatsku ${ }^{41}$ ovdje ćemo spomenuti samo jednu noviju presudu ESLJP-a, u kojoj je ponovio svoja stajališta o pristupu sudu u kontekstu pitanja dovodi li odbačaj građanske tužbe koji je posljedica neispunjenja zakonske pretpostavke da se prije podnošenja tužbe protiv

39 Vidi Željko Potočnjak, Pravo na sud, pristup sudu i suđenje u razumnom roku u slučaju intervencije zakonodavca u sudske postupke u tijeku, Zbornik Pravnog fakulteta Sveučilišta u Rijeci, 25, 2004, br. 2., str. 823.-853.

40 Usp. Željko Potočnjak i Mirjana Stresec, Europski sud za ljudska prava i Ustavni sud Republike Hrvatske u zaštiti ljudskih prava u: Hrvatsko ustavno sudovanje de lege lata i de lege ferenda, Okrugli stol održan 2. travnja 2009. u palači HAZU u Zagrebu, str. 226. i 227.

41 Vidi i presude (sve protiv Hrvatske): Banović od 11.6.2015. (zahtjev br. 44284/10, nije povrijeđen čl. 6. st. 1.); . Čikanović od 5.2.2015. (zahtjev br. 27630/07 povreda čl. 6. st. 1.). Simecki od 30.4.2014. (zahtjev br. 15253/10, povreda čl. 6. st. 1.); Klauz od 18.7.2013. (zahtjev br. 28963/10, povreda i čl. 6. st. 1.); Peruško od od 15. siječnja 2013. (zahtjev br. 36998/09, Omerović (2) 5.12.2013., (zahtjev br. 22980/09, utvrđena i povreda čl. 6. st. 1.), utvrđena povreda članka 6. stavka 1.), .); Čamovski, od 23.10.2012. (zahtjev br. 38280/10, povreda čl. 6. st. 1., ESLJP zaključuje da je Ustavni sud u konkretnom predmetu očigledno pogriješio odnosno pogrešno računao rok u kojem je podnositelj dostavio ustavnu tužbu prije nego je odbacio ustavnu tužbu kao nepravovremenu. Stoga je podnositelju povrijeđeno pravo na pristup sudu.); Majski (2) od 19.7.2011. (zahtjev br. 16924/08, utvrđena povreda članka 6. stavka 1.), Vrbica od 1.4.2010. (zahtjev br. 32540/05, povreda i čl. 6. st. 1.); Biondić od 8.11.2007. (zahtjev br. 38355/05, povreda čl. 6. st. 1.), Lesjak od 18.2.2010. (zahtjev br. 25904/06, povreda čl. 6. st. 1.); Truhli od 28.6.2001. (zahtjev br. 45424/99, nije povrijeđen čl. 6 st. 1.). 
države podnese zahtjev za mirno rješavanje spora do povrede prava na pristup sudu. U presudi Momčilović protiv Hrvatske od 26. ožujka $2015 .{ }^{42}$ ESLJP je naveo da je više puta u presudama isticao da je u članak 6. stavak 1. Konvencije ugrađeno "pravo na sud" (right to court), u kojemu pravo pristupa (right of access), to jest pravo na pokretanje postupka pred sudom, predstavlja samo jedan od aspekta. Međutim, to je onaj aspekt koji omogućuje pojedincu korist od daljnjih jamstava navedenih u stavku 1. članka 6. Konvencije. Pošten (pravičan; the fair), javan (public) i brz (expeditious) postupak karakteristike su sudskih postupaka koji doista nemaju vrijednost ako se takav postupak prvo ne pokrene. U građanskim stvarima teško da se može i zamisliti vladavina prava bez mogućnosti pristupa sudovima. Pravo na pristup sudu nije, međutim, apsolutno i može biti predmet legitimnih ograničenja. Kad je pristup sudu nekog pojedinca ograničen, ili silom zakona ili u stvari (u praksi; in fact), ESLJP će ispitati je li nametnuto ograničenje ugrozilo (umanjilo; impaired) bit (suštinu; essence of the right) prava te, osobito, je li težilo ostvarenju legitimnog cilja, kao i je li postojao razuman odnos razmjernosti između upotrijebljenih sredstava i cilja koji se želio ostvariti. ${ }^{43}$ Neće doći do povrede članka 6. Konvencije ako je ograničenje u skladu s tim načelima (vidi Z. $i$ dr. protiv Ujedinjenog Kraljevstva, citirano, $\S \S 92-93$ ).

U konkretnom slučaju podnositelji su tražili naknadu štete od države zbog ubojstva njihove kćeri, odnosno sestre. U siječnju 1998. godine podnijeli su zahtjev za mirno rješenje spora nadležnom državnom odvjetništvu, koje je odbilo taj zahtjev. Podnositelji su potom podnijeli tužbu za naknadu štete nadležnom sudu, koja je kasnije povučena. U svibnju 2005. godine podnositelji su pokrenuli novi parnični postupak za naknadu štete. Međutim, domaći sudovi su odbacili tužbu za naknadu štete jer podnositelji prethodno nisu podnijeli zahtjev za mirno rješenje spora nadležnom državnom odvjetništvu, sukladno Zakonu o parničnom postupku. ESLJP je utvrdio da je ograničenje prava na pristup sudu, kao obveza da se podnese zahtjev za mirno rješenje spora nadležnom državnom odvjetništvu prije podnošenja tužbe za naknadu štete sudu, bilo propisano zakonom. Ono je imalo legitiman cilj - smanjenje broja sudskih postupaka za naknadu štete protiv države i omogućavanje izvansudskog rješavanja sporova. ESLJP je ocijenio da zakonski uvjet prethodnog podnošenja zahtjeva za mirno rješenje spora nije stvorio nikakvu štetu podnositeljima. Čak i nakon što je njihova tužba odbačena zbog neispunjavanja tog uvjeta, podnositelji su još uvijek mogli podnijeti zahtjev za mirno rješenje spora nadležnom državnom odvjetništvu, te u slučaju odbijanja tog zahtjeva, podnijeti novu tužbu za naknadu štete nadležnom sudu u zakonskim rokovima. Štoviše, podnositelji nisu precizirali na koji je način obveza podnošenja zahtjeva za mirno rješenje spora negativno utjecala na njihova prava, osim što bi eventualno morali poduzeti dodatnu procesnu radnju. ESLJP je utvrdio da su sami podnositelji, time

42 Zahtjev br. $11239 / 11$

43 Vidi Ashingdane protiv Ujedinjenog Kraljevstva, 28. svibnja 1985., § 57., Serija A br 93, Zwiazek Nauczycielstwa Polskiego protiv Poljske, zahtjev br. 42049/98, § 29., ECHR 2004-IX i Szwagrun-Baurycza protiv Poljske, presuda, 24. listopada 2006., zahtjev br. 41187/02, § 49. 
što su propustili ispuniti ovaj procesni uvjet, onemogućili domaćim sudovima da meritorno odlučuju u njihovom predmetu te da stoga nije došlo do povrede članka 6. Konvencije. U ovoj je presudi ESLJP podržao stajališta Vijeća Europe, koja su izražena u dokumentima koji su citirani u samoj presudi, o poticanju alternativnih oblika rješavanja sporova kako bi se smanjila preopterećenost sudova. ${ }^{44}$

\section{STAJALIŠTA USTAVNOG SUDA REPUBLIKE HRVATSKE}

Pretražujući praksu Ustavnog suda pod pojmom "pristup sudu", u ustavnosudskoj bazi podataka otvara se preko 1000 dokumenata. Zbog toga su u ovom radu analizirane uglavnom one odluke koje se odnose na građanski aspekt članka 29. Ustava (koji uključuje i upravni aspekt) i koje su objavljene na internetskim stranicama Ustavnog suda i/ili u Narodnim novinama. Razvoj prava na pristup sudu odnosno tumačenje sadržaja ovog prava, kao jednog od aspekata pravičnog suđenja, kroz praksu i stajališta Ustavnog suda prikazat ćemo kronološki.

\subsection{Početna obrazlaganja povrede prava na pristup sudu}

Najstarija odluka koju smo pronašli, u kojoj je Ustavni sud u svojoj ocjeni spomenuo pristup sudu, jest odluka donesena za vrijeme prvog sastava Ustavnog suda Republike Hrvatske. ${ }^{45}$ Riječ je o odluci broj: U-III-336/1993 od 1. lipnja 1994. ${ }^{46}$ Komisija za dodjelu stanova dodijelila je 1990. godine stan podnositelju ustavne tužbe, no dvije godine kasnije isti stan dodijelila je drugoj osobi. Podnositelj je podnio tužbu Upravnom sudu, koji je njegovu tužbu odbacio, ocijenivši da osporena odluka ne predstavlja upravni akt u smislu članka 6. Zakona o upravnim sporovima (u daljnjem tekstu: ZUS/91) ${ }^{47}$ Prema ocjeni Ustavnog suda osporena odluka donesena je na temelju općeg akta te ima karakter upravnog akta iz članka 6. ZUS-a/91, protiv kojeg je dopušten upravni spor. Ustavni sud je stoga usvojio ustavnu tužbu, ukinuo osporeno rješenje Upravnog suda i predmet vratio tom sudu na ponovni postupak. U obrazloženju je Ustavni sud naveo: "Kako je Upravni sud

44 Znatan je broj odluka ESLJP-a u kojima je prigovor o povredi prava na pristup sudu odbačen kao neosnovan. Dajemo primjere odluka: Damjanović, Đuro, 25.8.2015., zahtjev br. 5306/13; Kovačević, Alen, 30.6.2015., zahtjev br. 61763/13; Sekul, Zorislav, 30.6.2015., zahtjev br. 43569/13, ovršni postupak; Grubić protiv Hrvatske od 9.6.2015., zahtjev br. 56094/12; Žarković, Sava i dr., 9.6.2015., zahtjev br. 75187/12; Vuković, Slavko, 25.11.2014., zahtjev br. 23662/12; Kovačević, Jelena i dr., 8.7.2014., zahtjev br. 45903/08; Bogdanović, Savo i $d r$., 18.3.2014., zahtjev br. 72254/11, parnični postupak radi naknade štete; Smiljan Pervan, Larisa, 4.3.2014., zahtjev br. 31383/13.; Baničević, Ante i Marija, 2.10.2012., zahtjev br. 44252/10; Kontić-Draščić, Marina i Brankica, 25.9.2012., zahtjev br. 20428/09.

45 Sastav Ustavnog suda s prvim predsjednikom Ustavnog suda, dr. sc. Jadrankom Crnićem.

46 Odluka je objavljena u Narodnim novinama, br. 50/94.

47 Zakon o upravnim sporovima, Narodne novine, br. 53/91, 9/92 i 77/92 U ovom članku ZUS iz 1991. označavat će se kao ZUS/91, a ZUS iz 2010. (Narodne novine, broj 20/10, 143/12 i 152/14) kao ZUS/10. 
Republike Hrvatske odbacio tužbu kao nedopuštenu, uskratio je tužitelju pravo na pristup sudu i time povrijedio ustavno pravo tužitelja na pravnu zaštitu protiv pojedinačnog akta, zajamčeno mu člankom 18. Ustava Republike Hrvatske". Za razliku od navedene odluke, u odluci U-III-504/1996 od 8. srpnja 1999.48 pravo na pristup sudu Ustavni sud je "povezao" s pravom na pravično suđenje. Riječ je bila o podnositelju koji je 1973. godine, za vrijeme odsluženja vojnog roka u bivšoj JNA, zadobio teške tjelesne ozljede. Pravomoćnom presudom iz 1978. godine podnositelju su djelomično dosuđeni određeni iznosi na ime naknade štete. Prvostupanjska presuda djelomično je ukinuta i predmet je bio vraćen prvostupanjskom sudu na ponovno suđenje. Prvostupanjski sud postupak je prekinuo jer je tuženik (SFRJ - SSNO) prestao postojati. Podnositelj je 1992. godine, podneskom, predložio nadležnom sudu nastavak postupka te označio kao tuženicu Republiku Hrvatsku. Republika Hrvatska se protivila preinaci tužbe i nije preuzela parnicu, jer nije pravni sljednik SFRJ. Rješenjem koje je osporeno ustavnom tužbom, prvostupanjski sud je ocijenio da je riječ o preinaci tužbe, a ne o nastavljanju prekinutog postupka te je odlučio da preinaku tužbe ne dopusti. Žalba podnositelja je odbijena, a revizija odbačena "jer da se revizijom pobija rješenje kojim se postupak pravomoćno ne okončava". U ovom predmetu pred Ustavnim sudom pojavilo se pitanje, zbog čega je održan i konzultativni sastanak: "Da li je Republika Hrvatska pravni sljednik bivše SFRJ u nedovršenim (prekinutim) parničnim postupcima koje su radi naknade osobnih šteta pokrenuli i vodili građani Republike Hrvatske (državljani i oni s priznatim trajnim nastanjenjem na dan 8. listopada 1991.) protiv bivše SFRJ?" Konzultativni sastanak potvrdno je odgovorio na to pitanje, a Ustavni sud izrazio je stajalište: "Postojanje odgovornosti za obveze bivše države, dakle, neupitno je i ne može biti predmetom sukcesije u predmetima kakav je konkretni. Predmetom sukcesije, prema tome, teorijski može biti samo opseg i visina te odgovornosti, a praktično - pitanje visine odgovornosti može i treba biti predmetom naknadnih kompenzacija. U tom svjetlu ukazuje se neprihvatljivom apriorna uskrata prava na pristup sudu, prava na pravično suđenje i mogućnosti ostvarenja stečenih prava građaninu - vlastitom državljaninu pred sudom vlastite države, koja mu prema kriteriju prebivališta odnosno prema teritorijalnom principu, a i drugim kriterijima, pripadaju."

Odlukom broj: U-III-1469/2002 od 28. listopada 2002. Ustavni sud usvojio je ustavnu tužbu i ukinuo rješenje Vrhovnog suda kojim je zbog pogrešno utvrđene činjenice dostave drugostupanjske presude podnositeljici, odbačen, kao nepravodoban, njezin zahtjev za izvanredno preispitivanje pravomoćne presude. Ustavni sud utvrdio je da je podnositeljici "povrijeđeno pravo na pravično suđenje u dijelu koji se odnosi na pristup sudu iz odredbe članka 29. stavka 1. Ustava."

Kao što je već navedeno, pod utjecajem presuda Kutić i Multiplex Ustavni sud je u predmetima vezanim uz razumni rok u kojima su parnični postupci radi naknade štete protiv države prekinuti po sili zakona, osim povrede prava na suđenje

48 Odluka je objavljena u Narodnim novinama, br. 80/99. 
u razumnom roku, razmatrao i povredu prava na pristup sudu. Na presudu Kutić protiv Hrvatske pozivalo se i dvadesetak podnositelja kojima je po sili Zakona o davanju u najam stanova na oslobođenom teritoriju ${ }^{49}$ prestalo stanarsko pravo. Tim Zakonom naime, bio je propisano, kao uvjet za zadržavanje stanarskog prava, povratak nositelja tih prava u stanove do 26. prosinca 1995. Podnositelji su podnijeli prijedloge za pokretanje postupka za ocjenu suglasnosti s Ustavom tog zakona, kao i Zakona o prestanku važenja Zakona o davanju u najam stanova na oslobođenom teritoriju, ${ }^{50}$ ali i ustavne tužbe kojima su u biti osporavali navedene zakone, a ne pojedinačne akte. Sve te ustavne tužbe su odbačene, ${ }^{51}$ a u odnosu na prigovor podnositelja, temeljen na presudi Kutić protiv Hrvatske da su bili faktički onemogućeni vratiti se u Republiku Hrvatsku odnosno da nisu uopće imali "mogućnost za vođenje postupka za zaštitu svog povrijeđenog prava", Ustavni sud podsjetio je na konačnu odluku o dopuštenosti zahtjeva u predmetu Ostojić protiv Hrvatske, ${ }^{52}$ kojom je ESLJP odbacio zahtjev podnositelja kao očito neosnovan, utvrdivši, uz činjenicu da nije pokrenuo nikakav parnični postupak radi naknade štete protiv države, i naveo sljedeće: "Glede podnositeljeve tvrdnje da nije mogao podnijeti građansku tužbu u Hrvatskoj zato što nije bio u mogućnosti ući u Hrvatsku, Sud bilježi da je, čak i pod pretpostavkom da je podnositelj osobno bio spriječen da uđe u Hrvatsku, on mogao koristiti usluge druge osobe koje ga je mogla zastupati pred hrvatskim vlastima ili je mogao komunicirati sa hrvatskim vlastima putem pošte."

\subsection{Definicija prava na pristup sudu u praksi Ustavnog suda}

Prvu definiciju prava na pristup sudu, kojom se, uz neke dopune i korekcije, i danas služi, Ustavni sud je naveo u predmetu apstraktne kontrole, u rješenju broj: U-I-949/1995 i dr. od 23. studenoga 2005., ${ }^{53}$ ocjenjujući suglasnost s Ustavom Zakona o sudskim pristojbama. Predlagatelji su osporavali visinu iznosa navedenih u Tarifi sudskih pristojbi smatrajući ih previsoko određenima, odnosno nepravičnima te protivnima "duhu” Ustava. Pošavši od članaka 16. i 29. stavka 1. Ustava, Ustavni sud izrazio je sljedeće stajalište: "Pravo pravičnog suđenja, zajamčeno člankom 29. stavkom 1. Ustava, obuhvaća više aspekata koji čitav proces suđenja čine pravičnim. U svojoj biti to je postupovno jamstvo koje zahtijeva da postupak od strane državnih tijela bude proveden prema načelima koja će strankama u postupku osigurati pravično suđenje.// Pravo svakoga na pristup sudu dio je temeljnog ljudskog prava na pravično suđenje, a podrazumijeva pristupačnost postupku sa

49 Zakon o davanju u najam stanova na oslobođenom teritoriju, Narodne novine, broj 73/95.

50 Zakon o prestanku važenja Zakona o davanju u najam stanova na oslobođenom teritoriju, Narodne novine, broj 101/98.

51 Npr. rješenje br. U-III-2962/2002 od 14. svibnja 2004., Narodne novine, broj 77/04 i www. usud.hr i druga rješenja

52 Odluka ESLJP-a od 26. rujna 2002., zahtjev br. 16837/02.

53 Rješenje je objavljeno na www.usud.hr. 
svim obilježjima sudskog oblika ispitivanja. I samo pravo na pristup sudu ima nekoliko aspekata. Mogućnost iniciranja sudskog postupka radi donošenja odluke o pravima i obvezama stranaka, iako sama po sebi nije dovoljna da bi se osiguralo pravo pristupa sudu, onaj je aspekt prava na pristup sudu bez kojega ostala jamstva, sadržana u pravu pravičnog suđenja, ne bi mogla imala pravno značenje.// Pravo na pristup sudu, međutim, nije apsolutno; ono može biti zakonom ograničeno (članak 16. Ustava); primjerice zakonom određenim pretpostavkama koje moraju biti ispunjene za podnošenje tužbe ili rokovima za ulaganje pravnih lijekova. Različita ograničenja mogu svesti pravo na pristup sudu na razinu koja bi dovela do toga da je sama bit ostvarenja tog prava ugrožena. Svako ograničenje, stoga, mora biti ustanovljeno zakonom, mora imati legitimni cilj te mora postojati razumna razmjernost između ograničenja i cilja koji se tim ograničenjem želi postići."

Imajući u vidu, između ostalog, da Zakon propisuje i mogućnost oslobađanja od plaćanja sudskih pristojbi, Ustavni sud je ocijenio da Zakonom propisani sustav plaćanja sudskih pristojbi, kao ni Tarifa sudskih pristojbi, sami po sebi ne predstavljaju ograničenje prava na pristup sudu. S druge strane, primjena Zakona i Tarife na konkretan slučaj može dovesti do ograničenja prava na pristup sudu. Iznos pristojbe koji je sud naložio platiti ili pak propust suda da stranku oslobodi od plaćanja pristojbe, procijenjen u svjetlu okolnosti konkretnog slučaja, uključujući sposobnost stranke da je plati, vrijednost predmeta spora, kao i faze postupka u kojoj je nametnuta obveza plaćanja pristojbe, elementi su koji određuju je li u konkretnom pojedinačnom slučaju stranci onemogućen pristup sudu ili nije. No, primjena propisa na konkretan slučaj može biti predmet ispitivanja samo u postupku konkretne kontrole koji se pred Ustavnim sudom pokreće ustavnom tužbom, a ne i u postupku apstraktne kontrole.

\subsection{Suglasnost zakona s Ustavom s aspekta prava na pristup sudu}

Osim Zakona o sudskim pristojbama, Ustavni sud ocjenjivao je, s aspekta prava na pristup sudu, suglasnost s Ustavom više zakona, npr.: Zakon o radu (rješenje broj: U-I-490/2000 od 22. prosinca 2004.,), ${ }^{54}$ Zakon o besplatnoj pravnoj pomoći (odluka i rješenje broj: U-I-722/2009 od 6. travnja 2011.), ${ }^{55}$ Ovršni zakon (odluka broj: U-I-1988/2011 i dr. od 19. lipnja 2012.), ${ }^{56}$ kao i Zakon o parničnom postupku (rješenje broj: U-I-4365/2008 i dr. od 26. ožujka 2013.) ${ }^{57}$ U nastavku dajemo kratki prikaz tih odluka.

54 Objavljeno u Narodnim novinama, br. 5/05.

55 Objavljeno u Narodnim novinama br. 44/11.

56 Objavljeno u Narodnim novinama, br. 80/12.

57 Objavljeno u Narodnim novinama, br. 43/13. 


\subsubsection{Zakon o radu $u^{58}$}

U konkretnom ustavnosudskom predmetu bila je osporena odredba članka 184. stavka 2. Zakona o radu, koja je propisivala da se postupak za zabranu djelovanja udruge pokreće na zahtjev tijela ovlaštenog za registraciju ili ovlaštenog državnog odvjetnika. Predlagatelj je smatrao da je tim ograničenjem "građanima koji bi bili 'grubo oštećeni od sindikata/povjerenika' onemogućen pristup sudu". Ustavni sud je ocijenio da predlagatelj polazi od pogrešne pretpostavke da je u slučaju povrede određenih prava pojedinca od strane sindikata ili povjerenika jedini pravni put postupak za zabranu djelovanja udruge. Naime, prema stavku 1. članka 184. županijski sud zabranit će djelovanje udruge ako utvrdi da je njezina djelatnost protivna Ustavu i zakonu, a ne i ako je svojim (ne)postupanjem sindikat ili povjerenik povrijedio određena prava pojedinca. U ovom posljednjem slučaju pojedinac može radi zaštite svojih prava i obveza protiv sindikata pokrenuti druge postupke unutar pozitivnog zakonodavstva Republike Hrvatske. Sindikat je pravna osoba, ima pravnu i stranačku sposobnost, što znači da može biti stranka u postupku. Ustavni sud je podsjetio i na odredbe Zakona o državnom odvjetništvu, ${ }^{59}$ prema kojima je državno odvjetništvo (koje je jedan od ovlaštenika na podnošenje zahtjeva za zabranu rada udruge) dužno od građana, državnih tijela i pravnih osoba primati prijave, podneske i izjave u stvarima iz svoga djelokruga radi poduzimanja radnji sukladno svojim ovlastima. Ustavni sud je ocijenio da je zakonodavac postupio u granicama ovlasti propisane Ustavom.

\subsubsection{Zakon o besplatnoj pravnoj pomoći $i^{60}$}

Ustavni sud je ukinuo više odredbi tog zakona, "kojim se razrađuje temeljno ustavno pravo na pristup sudu". Ističemo samo ocjenu onih odredbi Zakona o besplatnoj pravnoj pomoći (u daljnjem tekstu ZBPP) koja se odnosi na pristup sudu. Zakonodavac je u članku 5. stavku 1. ZBPP-a propisao pravnu obvezu nadležnih tijela državne uprave da odobre ostvarivanje pravne pomoći u svim postupcima pred sudovima, upravnim tijelima i drugim pravnim osobama s javnim ovlastima, ako se njima rješava o egzistencijalnim pitanjima korisnika. Ustavni sud je primijetio da neodređeni pravni pojam "egzistencijalnog pitanja" ozbiljno narušava tu pravnu obvezu nadležnih tijela državne uprave. Unatoč pokušaju zakonodavca da neodređeni pravni pojam "egzistencijalnog pitanja" bliže odredi navođenjem primjera koji bi trebali poslužiti nadležnim tijelima državne uprave kao smjernice za postupanje u praksi, Ustavni sud je ocijenio da sadržaj i struktura članka 5. stavka 2. ZBPP-a ne daje osnovu za zaključak da će svrha članka 5. stavka 1. ZBPP-a u praktičnom pravnom životu biti ostvarena te da stoga članak 5. stavak 2. ZBPP-a ne udovoljava zahtjevima pravne sigurnosti objektivnog pravnog poretka i da je

58 Zakon o radu, Narodne novine, br. 38/95, 54/95, 65/95, 17/01, 82/01, 114/03, 123/03, 142/03 i 30/04.

59 Zakon o državnom odvjetništvu, Narodne novine, br. 51/01.

60 Zakon o besplatnoj pravnoj pomoći, Narodne novine, br. 62/08. 
protivan postupovnim pravilima koja proizlaze iz prava na pristup sudu odnosno prava na pravično suđenje u vezi sa zahtjevima koji proizlaze iz vladavine prava kao najviše vrednote ustavnog poretka Republike Hrvatske (članak 3. Ustava). Tim zahtjevima, prema ocjeni Ustavnog suda ne udovoljava ni članak 10. stavak 2. ZBPP-a, kojim je bilo propisano da odvjetnik ne smije odbiti pružiti pravnu pomoć u skladu s odredbama ovoga Zakona, osim u slučajevima predviđenima Zakonom o odvjetništvu za uskratu pravne pomoći. Zakon o odvjetništvu, u članku 9., navodi razloge zbog kojih je odvjetnik dužan uskratiti pružanje pravne pomoći, no u istom članku upućuje i na druge razloge sadržane u Kodeksu odvjetničke etike. Prema stajalištu Ustavnog suda, dvostruko upućivanje na mjerodavnu normu o dopuštenoj uskrati pravne pomoći potencijalnom korisniku pravne pomoći zapravo onemogućuje ostvarenje njegova prava na pristup sudu. Što se tiče razloga uskrate pravne pomoći, neki razlozi iz Zakona o odvjetništvu primjenjivi su i na besplatnu pravnu pomoć, no njihov dio, sadržan u Kodeksu, prema ocjeni Ustavnog suda, široko je i neodređeno postavljen, a za pogođenog korisnika nije predvidljiv niti mu omogućava bilo kakvo sredstvo kontrole tih razloga. Kod korisnika besplatne pravne pomoći ti razlozi moraju biti uži i precizniji od onih koje propisuje Zakon o odvjetništvu za opći režim pružanja pravne pomoći od odvjetnika, jer se ta norma ne smije pretvoriti u mogućnost da većina odvjetnika uopće ne pruža besplatnu pravnu pomoć, pozivajući se na razloge svrsishodnosti, preopterećenosti i sl. Takva bi mogućnost potpuno poništila temeljnu svrhu ZBPP-a. Članak 37. ZBPP-a koji govori o obvezi korisnika da u slučaju uspjeha u postupku, ako mu "sud dosudi imovinu ili primitak", vrati primljeni iznos po "uputnici" u državni proračun, prema ocjeni Ustavnog suda, toliko je manjkav da onemogućuje u velikoj mjeri predvidljiv i funkcionalan sustav zaštite prava na pristup sudu i tako krši pravo na pravično suđenje, u vezi sa zahtjevima koji proizlaze iz vladavine prava kao najviše vrednote ustavnog poretka Republike Hrvatske (članak 3. Ustava).

\subsubsection{Ovršni zakon ${ }^{61}$}

Člankom 338. stavkom 1. Ovršnog zakona (u daljnjem tekstu: Ovršni zakon/10) bilo je propisano da će se postupci koji su u tijeku, a pokrenuti su prije stupanja na snagu Ovršnog zakona, ${ }^{62}$ obustaviti u roku od tri mjeseca od dana stupanja na snagu Ovršnog zakona/10, ako ovrhovoditelj ne podnese osnovani prijedlog na temelju kojeg se postupak može nastaviti. Ustavni sud je pošao od stajališta o pravu na pristup sudu izraženog u rješenju U-I-949/2005 i o zahtjevu za određenošću i preciznošću pravne norme izraženom u odluci U-I-722/2009. Osim što osporena norma ne zadovoljava zahtjeve načela vladavine prava, tj. neodređena je i neprecizna, Ustavni sud je ocijenio i da takvo normativno rješenje ujedno dovodi i do uskrate prava na pristup sudu, "jer se postupci započeti po Zakonu o izvršnom

61 Ovršni zakon, Narodne novine, br. 139/10, 125/11, 150/11, 154/11 i 12/12.

62 Ovršni zakon, Narodne novine, br. 57/96, 29/99, 42/00, 173/03, 194/03, 151/04, 88/05, $121 / 05$ i $67 / 08$. 
postupku obustavljaju, a da za takvo postupanje nisu navedeni razlozi koji bi bili usklađeni sa zahtjevima pravne sigurnosti iz članka 3. Ustava”. Pored toga, Ustavni sud je utvrdio da obustavom postupka zbog nedostavljanja "osnovanog prijedloga" za nastavak ovršnih postupaka i postupaka izvršenja, građani odnosno vjerovnici ostaju bez mogućnosti naplate svojih tražbina, jer obustavom postupka prestaje postupak ovrhe, kojemu je glavni cilj naplata tražbina između građana i pravnih osoba, odnosno subjekata građanskopravnih odnosa. Uskratom odgovarajućeg pravnog puta kojima mogu ostvariti svoje tražbine, odnosno svoja prava, građani gube i pravo pristupa sudu. Ovo iz razloga što većina postupaka koji se vode po Zakonu o izvršnom postupku traju najmanje 15 godina, te propisivanjem da se $\mathrm{u}$ roku od tri mjeseca mora podnijeti "osnovani prijedlog" a da se ne odredi oblik i sadržaj tog prijedloga, prema ocjeni Ustavnog suda dovodi do uskraćivanja prava na pristup sudu te do nesuglasnosti članka 338. stavka 1. Ovršnog zakona s člankom 29. stavkom 1. Ustava. Ustavni sud je ukinuo članak 338. stavak 1. Ovršnog zakona. $^{63}$

\subsubsection{Zakon o parničnom postupku $u^{64}$}

U ustavnosudskom postupku osporen je članak 91.a Zakona o parničnom postupku ( $\mathrm{u}$ daljnjem tekstu: ZPP), koji propisuje da stranka može podnijeti reviziju samo putem opunomoćenika koji je odvjetnik, odnosno osobe koja ima položen pravosudni ispit. Prijedloge je podnijelo 26 predlagatelja; svi su smatrali da se osporenim člankom 91.a ZPP-a ograničava pristup sudu i time mogućnost da svi građani dobiju jednaku sudsku zaštitu pred Vrhovnim sudom. Primjenjujući načelna stajališta o pristupu sudu na osporeni članak ZPP-a, Ustavni sud je u ustavnosudskom postupku postavio pitanje: Je li zakonsko ograničenje propisano člankom 91.a ZPP-a dovelo u pitanje samu bit prava na pristup sudu?

Imajući u vidu strukturu i funkcioniranje parničnog postupka (do pravomoćnosti smatra se redovnim postupkom, a nakon pravomoćnosti iznimkom za posebne slučajeve), Ustavni sud je utvrdio da su "razlozi racionalne organizacije sustava pravnih lijekova, pravne sigurnosti i ekonomičnosti nametnuli potrebu višestrukog ograničenja mogućnosti njihova podnošenja (vrsta pravnih lijekova, osoba koje su ih ovlaštene podnositi, rokova u kojima se mogu podnijeti i dr.). Opće je obilježje tih ograničenja da se ona pojačavaju što je viši stupanj suda koji treba

63 Zakonodavac je donio novi Ovršni zakon, Narodne novine, br. 112/12, koji je sadržavao gotovo istu odredbu u članku 369. stavku 2. Troje predlagatelja osporilo je tu odredbu ističući da je zakonodavac svjesno išao "za eskiviranjem odluke Ustavnog suda". Rješenjem broj: U-I-5345/2012 i dr. od 23. prosinca 2014. Ustavni sud nije prihvatio prijedloge. Iako je utvrdio da zakonodavac nije postupio u cijelosti u skladu s pravnim stajalištima Ustavnog suda (izostavio je jedino riječ "osnovani" koji je bio i najozbiljniji prigovor Ustavnog suda u prvoj odluci), ocijenio je da priroda i značaj ovog predmeta nisu takvi da je nužno ponovo ukidati, u biti istu, odredbu.

64 Zakon o parničnom postupku, Narodne novine, broj 53/91, 91/92, 112/99, 88/01, 117/03, $88 / 05,2 / 07,84 / 08,123 / 08$ i 57/11. 
odlučiti o pravnom lijeku. Naime, nakon pravomoćnosti sudske odluke procesna prava stranaka ne prestaju nego se 'sužavaju', a radi postizanja cilja dopuštenog izvanrednog pravnog lijeka.” Revizija je izvanredni pravni lijek, koja se podnosi protiv drugostupanjske sudske odluke kojom se postupak pravomoćno završava i o kojoj odlučuje Vrhovni sud ispitujući zakonitost odluka nižestupanjskih sudova. Ona je, prema stajalištu Ustavnog suda, nužno po prirodi parničnog postupka složeniji pravni lijek (u odnosu na žalbu kao redovni lijek), za čije su podnošenje utvrđene strože pretpostavke, a razlozi zbog kojih se može podnijeti su ograničeni. Polazeći od toga da se u revizijskom postupku preispituje materijalna i postupovna zakonitost pobijane presude (rješenja), a ne i pravilnost utvrđenja činjeničnog stanja, Ustavni sud je utvrdio da je zakonodavac propisujući krug kvalificiranih osoba koje mogu podnijeti reviziju naglasio potrebu da se u revizijskom postupku, u kojem se odlučuje isključivo o pravnim pitanjima, osigura viša razina stručnih znanja i kvalitete u zastupanju stranaka a time veća kvaliteta odlučivanja u pojedinom slučaju, a što doprinosi većoj pravnoj sigurnosti stranaka. Prema ocjeni Ustavnog suda "propisani zahtjev vezan za odvjetnika odnosno za osobu koja ima položen pravosudni ispit nije strukturno ograničenje koje onemogućuje pristup sudu”. ${ }^{65}$

\subsection{POJEDINAČNI SLUČAJEVI}

U nastavku ćemo prikazati predmete koje smo izdvojili iz bogate ustavnosudske prakse u ovom području, kao primjere tumačenja sadržaja prava na pristup sudu u individualnoj ustavnosudskoj kontroli.

\subsubsection{Pogrě̌na uputa o pravnom lijeku}

Pogrešna uputa o pravnom lijeku, ako se stranka na nju osloni, u pravilu će dovesti do povrede prava na pristup sudu, posebice ako se odnosi na pogrešan rok za podnošenje pravnog lijeka. Stajalište je Ustavnog suda da pogrešna uputa o pravnom lijeku ne smije ići na štetu stranke, pa ni onda kada stranku zastupa odvjetnik, koji je kao stručna osoba upoznat sa zakonskim rokovima za podnošenje pravnog lijeka. Zauzimajući to stajalište Ustavni sud je pošao od temeljne pretpostavke "da sudovi

65 Prema praksi Ustavnog suda rješenje Vrhovnog suda kojim odbacuje reviziju primjenom članka 91.a ZPP nije pojedinačni akt iz članka 62. Ustavnog zakona o Ustavnom sudu Republike Hrvatske (Narodne novine, broj 99/99, 29/02 i 49/02, u daljnjem tekstu: Ustavni zakon) u povodu kojega bi Ustavni sud bio nadležan pružiti ustavnosudsku zaštitu (primjerice rješenja: U-III-53/2014 od 20. veljače 2014., U-III-7251/2014 od 8. prosinca 2014., U-III-177/2015 od 19. veljače 2015., sva rješenja na www.usud.hr). Tu svoju praksu Ustavni sud djelomice je promijenio nakon presude ESLJP Omerović (br. 2) protiv Hrvatske od 5. prosinca 2013. (zahtjev br. 22980/09), pa u slučaju kad su u ustavnoj tužbi podnesenoj u povodu takve odluke Vrhovnog suda prigovori o povredi prava na pristup sudu ozbiljni i dostatno obrazloženi, o takvoj ustavnoj tužbi Ustavni sud će meritorno odlučiti. To je razvidno iz odluka Ustavnog suda: U-III-62/2014 od 20. veljače 2014. i U-III-1793/2014 od 23. svibnja 2014. (obje na www.usud.hr). 
poznaju propise i da daju pravilnu i zakonitu uputu o pravnom lijeku. Stoga stranke postupanjem po pogrešnoj uputi o pravnom lijeku danoj od strane nadležnog suda, ne smiju trpjeti štetne posljedice." Ovo stajalište Ustavni sud izrazio je u odluci broj U-III-1733/2000 od 24. studenoga 2004., ${ }^{66}$ koja se odnosila na kazneni postupak no, primjenjivo je u svim postupcima. Primjerice, odlukom U-III-1917/2003 ${ }^{67}$ Ustavni sud je usvojio ustavnu tužbu podnositeljice koja je žalbu protiv prvostupanjskog rješenja o dosudi i predaji nekretnine ovrhovoditelju podnijela u roku od osam dana, sukladno uputi o pravnom lijeku. Drugostupanjski sud je odbacio žalbu utvrdivši da je rok za žalbu bio tri dana od dana isticanja rješenja na oglasnoj ploči suda. I odlukom broj U-III-2808/200768 Ustavni sud je usvojio ustavnu tužbu podnositeljice, čija je žalba protiv prvostupanjskog zemljišnoknjižnog rješenja bila odbačena kao nepravodobna. Žalbu je podnijela u roku od 30 dana (ispravno bi bilo peetnaest dana), kako je bila poučena uputom o pravnom lijeku. Nadalje, u predmetu U-III-3071/2006 ${ }^{69}$ riječ je bila o sporu male vrijednosti i žalbi podnesenoj u roku 15 dana, sukladno uputi o pravnom lijeku (ispravno bi bilo osam dana). Ustavni sud je ukinuo drugostupanjsko rješenje, kojim je žalba bila odbačena kao nepravodobna.

Međutim, neće svaki pogrešno naznačeni rok za podnošenje pravnog lijeka u uputi o pravnom lijeku dovesti do povrede prava na pristup sudu. U predmetu U-III$4056 / 2011^{70}$ također je bila riječ o sporu male vrijednosti. U uputi o pravnom lijeku bio je naznačen rok od 15 dana (ispravno osam dana), iz čega je podnositeljica zaključila da žalbu može podnijeti bez ograničenja u žalbenim razlozima. Da joj je bila dana pravilna uputa, tvrdila je u ustavnoj tužbi, tada bi njezina žalba "bila potpuno drugačije napisana, sa potpuno drugačijim razlozima." Drugostupanjski sud meritorno je odlučio o žalbi podnositeljice uzevši u razmatranje samo one prigovore koji se, u skladu sa ZPP-om, žalbom u takvoj vrsti spora mogu isticati. Polazeći od činjenice da je drugostupanjski sud žalbu podnositeljice meritorno razmotrio, Ustavni sud je ocijenio da podnositeljici nije onemogućeno pravo na pristup žalbenom sudu, pa joj stoga nije povrijeđena ni sama bit prava na pristup žalbenom sudu. Pritom je ocijenio da “pogrešna pouka o pravnom lijeku u presudi suda prvog stupnja nije bila od utjecaja na iznošenje žalbenih razloga podnositeljice protiv prvostupanjske presude donesene u postupku u sporovima male vrijednosti kao i na konačni ishod postupka". U predmetu U-III-1959/200571 podnositeljica je postupila po pogrešnoj uputi svog poslodavca te je protiv odluke o prestanku radnog odnosa podnijela tužbu općinskom sudu, umjesto da je u skladu s tada važećim Zakonom o osnovnim pravima iz radnog odnosa (u daljnjem tekstu: ZOPRO), ${ }^{72}$ podnijela zahtjev za zaštitu prava nadležnom tijelu svog poslodavca. Ustavni sud

66 Odluka broj U-III-1733/2000 od 24. studenoga 2004., Narodne novine, br. 179/04 i www. usud.hr.

67 Odluka broj U-III-1917/2003, U-III-1918/2003 od 21. lipnja 2006., www.usud.hr.

68 Odluka broj U-III-2808/2007 od 13. veljače 2008., Narodne novine, br. 26/08 i www.usud.hr.

69 Odluka broj U-III-3071/2006 od 18. ožujka 2009., Narodne novine, br. 42/09 i www.usud.hr.

70 Odluka broj U-III-4056/2011 od 3. prosinca 2014., www.usud.hr.

71 Odluka broj U-III-1959/2005 od 30. travnja 2008., Narodne novine, br. 59/09 i www.usud.hr.

72 Zakon o osnovnim pravima iz radnog odnosa, Narodne novine, br. 34/91. 
je usvojio ustavnu tužbu, no imao je u vidu "razloge koji govore protiv, ali i one koji govore u prilog usvajanju ustavne tužbe". "Protiv ustavne tužbe" Ustavni sud je našao sljedeće razloge: građani (njihovi zastupnici) moraju poznavati pravo (ignorantio iuris nocet); uputa (pouka) o pravnom lijeku nije esencijalni dio čak niti sudske parnične odluke, "pa onda pogotovo ne može biti kod odluke poslodavca koji nije državni organ i od kojeg se ne može tražiti veća postupovna jamstva nego što ih daje sud"; nisu sudovi bili ti koji su podnositeljicu spriječili u pravu na pristup sudu, a "relevantna povreda konvencijskog i ustavnog prava na pristup sudu može predstavljati samo odluka nekog od sudova". Ipak, Ustavni sud je ocijenio da pretežu razlozi u prilog usvajanju ustavne tužbe: zabluda o pravu (error iuris) u suvremenom pravu postaje moguća relevantna zabluda kao i zabluda o činjenicama (nema dvojbe da bi podnositeljica predmetne ustavne tužbe bila podnijela prigovor drugostupanjskom tijelu poslodavca da spornom (pogrešnom) pravnom uputom nije usmjerena izravno na sud); uputa o pravnom sredstvu jest esencijalni dio odluke poslodavca kada on odlučuje o pravu svog radnika - to proizlazi iz ZOPRO-a koji je svojom formulacijom uputu o pravnom sredstvu učinio bitnim dijelom odnosne odluke "pa je izostanak pravilne upute u predmetnom slučaju toliko veliki nedostatak da dovodi u pitanje i samu pravnu egzistentnost takve odluke"; hrvatski sudovi imaju pravo i obvezu međusobne suradnje, pa tako npr. ako zaprime stvar za koju nisu nadležni trebaju je ustupiti sudu koji je nadležan - u konkretnom slučaju trebali su zaprimljenu tužbu shvatiti kao prigovor u smislu ZOPRO-a i dostaviti ju drugostupanjskom tijelu poslodavca ("poslodavac, istina, nije 'drugi sud' pa niti 'drugi državni organ', ali su ustavne obveze pravičnog sudskog postupanja iz članka 29. stavka 1. Ustava i načelo privatnog prava o savjesnosti i poštenju /članka 4. ZOO/ svakako nalagali takvo postupanje koje je izostalo").

Drugačija je situacija kada je uputom o pravnom lijeku stranci “dano" pravo na pravni lijek na kojeg ona nema pravo. Primjerice, Ustavni sud je, odlukom broj: U-III-748/199973, odbio ustavnu tužbu podnositelja koji je na obrascu liječničke komisije Hrvatskog zavoda za zdravstveno osiguranje o njegovoj radnoj sposobnosti bio poučen da protiv tog "rješenja" može pokrenuti upravni spor. Upravni sud je tužbu podnositelja odbacio. Ustavni sud je ocijenio da osporeno rješenje liječničke komisije nije upravni akt kojim se odlučuje o pravima i obvezama stranke, bez obzira što nosi naslov "rješenje" i što sadrži pogrešnu uputu o pravnom lijeku. Prema stajalištu Ustavnog suda "takva pogrešna pouka nema nikakvih pravnih posljedica jer se poukom ne može stranci dati pravni lijek na kojeg ona po zakonu nema pravo". Iako je ovu ustavnu tužbu Ustavni sud sagledavao s aspekta prava na žalbu (jer je na povredu tog prava ukazivao podnositelj), čini se da bi do istog zaključka došao i da ju je razmatrao s aspekta prava na pristup sudu. U sličnom slučaju (stranka pogrešno upućena da može pokrenuti upravni spor) Ustavni sud je tužbu podnositeljice odbacio (tzv. meritorni odbačaj) ocijenivši da ne postoje pretpostavke za odlučivanje o biti stvari. U postupku javnog natječaja radi davanja 
u zakup poslovnog prostora općina je kao najpovoljniju prihvatila ponudu druge poljoprivredne zadruge. Žalba podnositeljice odbijena je. Iako je upućena da može pokrenuti upravni spor, Upravni sud je tužbu odbacio jer se u konkretnom slučaju radi o aktu raspolaganja vlasnika poslovnim prostorom a ne od rješavanju o nekom pravu ili obvezi stranke u upravnoj stvari, pa se u tom slučaju ne može voditi upravni spor. Ustavni sud je napomenuo "da pogrešna uputa o pravnom lijeku, navedena u aktu koji nema svojstvo upravnog akta, ne uzrokuje pravne posljedice jer se takvom poukom ne može sudioniku u javnom natječaju, raspisanom radi davanja u zakup poslovnog prostora, dati pravni lijek na koji on, na temelju Zakonu o zakupu i prodaji poslovnog prostora ("Narodne novine" broj 91/96., 124/97., 174/04. i 38/09.), nema pravo." ${ }^{74}$ Slično i u slučaju kada stranka ima pravo podnijeti žalbu u upravnoj stvari, a pogrešno je upućena da može pokrenuti upravni spor, stranka neće snositi štetne posljedice takve upute o pravnom lijeku. Naime, prema članku 210. stavku 6. Zakona o općem upravnom postupku iz $1991 .{ }^{75}$, u takvoj situaciji rok za žalbu teče od dana dostave rješenja suda kojim je tužba odbačena kao nedopuštena. U predmetu U-III-2248/200376 Ustavni sud je odbio ustavnu tužbu jer je ocijenio da je podnositelj, i pored pogrešno dane upute o pravnom lijeku, na temelju članka 210. točke 6 . ZUP-a/91 mogao podnijeti žalbu nadležnom tijelu.

O ozbiljnosti kojom Ustavni sud pristupa pogrešnoj uputi o pravnom lijeku i njezinim posljedicama na prava stranaka svjedoči i odluka Ustavnog suda broj U-IX2253/2012 i dr., ${ }^{77}$ donesena u postupku u povodu žalbe suca na odluku predsjednice suda i odluke Državnog sudbenog vijeća (u daljnjem tekstu: DSV), kojima je žalitelj, nakon odluke DSV-a o razrješenju od sudačke dužnosti, privremeno udaljen od obavljanja dužnosti suca na rok od tri (3) mjeseca, s pravom na jednu polovinu plaće, odnosno kojima je žalitelju svaka tri mjeseca produljeno privremeno udaljenje od obavljanja dužnosti suca (odluka broj: U-IX-2253/2012 i dr., nije na www. usud.hr). U tim odlukama žalitelj je pogrešno upućen da ima pravo podnijeti žalbu Ustavnom sudu. Naime, Ustavni sud je na vlastitu inicijativu ${ }^{78}$ pokrenuo postupak i ukinuo članke 71. stavak 2. i 74. stavak 2. Zakona o Državnom sudbenom vijeću, ${ }^{79}$ kojima je bila propisana nadležnost Ustavnog suda za odlučivanje o žalbi stegovnog progonitelja protiv odluke o stegovnoj odgovornosti suca i žalbi suca protiv odluke o privremenom udaljenju od obavljanja dužnosti ${ }^{80}$. Tim se odredbama proširila nadležnost Ustavnog suda izvan djelokruga njegovih poslova utvrđenih Ustavom,

74 Rješenje broj: U-III-1749/2007 od 25. studenoga 2010., www.usud.hr

75 Zakon o općem upravnom postupku, Narodne novine, br. 53/91 i 103/96, u daljnjem tekstu: ZUP/91.

76 Odluka broj U-III-2248/2003 od 16. veljače 2006., www.usud.hr

77 Odluka broj U-IX-2253/2012 i dr. od 18. prosinca 2013. (Arhiv USRH-a)

78 Na temelju članka 38. stavka 2. Ustavnog zakona Ustavni sud može i sam pokrenuti postupak za ocjenu suglasnosti zakona s Ustavom i ocjenu suglasnosti drugih propisa s Ustavom i zakonom.

79 Zakon o Državnom sudbenom vijeću, Narodne novine, br. 116/10., 57/11. i 130/11.

80 Odluka broj: U-I-5991/2012 od 23. siječnja 2013., Narodne novine, br. 13 od 30. siječnja 2013. 
a razrađenih Ustavnim zakonom. U konkretnom slučaju osporene odluke bile su donesene nakon ove odluke Ustavnog suda te su, dakle, sadržavale pogrešnu uputu o pravnom lijeku. Unatoč nenadležnosti Ustavnog suda da odlučuje o odlukama o privremenom udaljenju od obavljanja dužnosti, Ustavni sud je iznimno, zbog pogrešne upute o pravnom lijeku, žalbe žalitelja meritorno razmotrio.

\subsubsection{Odbačaj revizije $e^{81}$}

"Pogrešna" odluka Vrhovnog suda da reviziju odbaci zbog primjerice preniske vrijednosti predmeta spora ili "dijeljenja" vrijednosti predmeta spora na više postavljenih tužbenih zahtjeva može dovesti do povrede prava na pristup sudu, odnosno tom pravnom sredstvu. Nekoliko je odluka u kojima je Ustavni sud utvrdio takvu povredu. Primjerice odluke broj: U-III-58/2005, U-III-5027/2005, U-III-1421/2006, U-III-1921/2006, U-III-2646/2007, U-III-633/2010. ${ }^{82}$ Isto tako, "pogrešna" odluka Vrhovnog suda da odbaci izvanrednu reviziju ${ }^{83}$ može dovesti do povrede prava na pristup sudu. U dva slučaja u kojima je sukladno tadašnjim odredbama ZPP-a drugostupanjski (žalbeni) sud u izreci presude dopustio izjavljivanje izvanredne revizije, a Vrhovni sud ih odbacio, ocijenivši da "drugostupanjski sud ne samo da nije naveo razloge zbog kojih smatra da je neko pravno pitanje u ovom sporu važno za osiguranje jedinstvene primjene zakona i ravnopravnost građana, već takvo pitanje nije niti naznačio" odnosno "nije jasno zbog kojeg je to važnog pravnog pitanja drugostupanjski sud dopustio reviziju", Ustavni sud je usvojio ustavne tužbe ${ }^{84}$. Stav Vrhovnog suda ocijenio je neutemeljenim na "ustavnopravno prihvatljivom tumačenju mjerodavnog postupovnog prava", "formalističkim", protivnim "legitimnim očekivanjima stranaka", te stavom kojim se vrijeđaju ustavna načela i prava, među ostalima,

81 Više o postupanju Ustavnog suda u predmetima u kojima su osporena rješenja Vrhovnog suda o odbačaju revizije vidi u: Sandra Marković i Sanja Trgovac, Postupanje Ustavnog suda vezano uz reviziju i revizijske odluke, Hrvatska pravna revija, br. 11, studeni 2015. str. 71.84.

82 Odluke broj: U-III-58/2005 od 16. ožujka 2006., Narodne novine, br. 43/06 i www.usud. hr; U-III-5027/2005 od 22. ožujka 2006., Narodne novine, br. 58/06 i wwww.usud.hr; U-III-1421/2006 od 19. listopada 2006., www.usud.hr; U-III-1921/2006 od 28. siječnja 2009., Narodne novine, br. 18/09 i www.usud.hr; U-III-2646/2007 od 18. lipnja 2008., Narodne novine, br. 104/08 i wwww.usud.hr; U-III-633/2010 od 22. travnja 2010., Narodne novine, br. 60/10 i www.usud.hr.

83 U odluci broj: U-I-885/2013 od 11. srpnja 2014., Narodne novine, br. 89/14 Ustavni sud je napomenuo da termini redovna i izvanredna revizija nisu zakonski termini, već se koriste da bi se njima označile dvije pravne situacije u kojima se revizija može podnijeti, a koje se po pretpostavkama za njihovu dopuštenost (razlozima zbog kojih se mogu podnijeti) i po postupku koji se povodom njih provodi značajno razlikuju. U odlukama broj: U-III-1122/2013 od 4. studenoga 2014., Narodne novine, br. 149/14. i broj: U-III-3859/2012 od 4. studenoga 2014., Narodne novine, br. 146/14., naznačio je da je riječ o kolokvijalnom pravnom izrazu "izvanredna revizija"; njime se u svojoj praksi Ustavni sud služi.

84 Odluke broj: U-III-2838/2006 od 5. lipnja 2007., Narodne novine, br. 72/07. i www.usud.hr te U-III-1052/2007 od 4. svibnja 2011., Narodne novine, br. 55/11 i www.usud.hr 
pravo na pristup sudu (pravnom lijeku). Ustavni sud usvojio je i nekoliko ustavnih tužbi u slučajevima u kojima su izvanredne revizije, kako su sada regulirana ZPPom, odbačene, iako ih nije sve sagledavao s aspekta prava na pristup sudu već $\mathrm{i}$ s aspekta (ne)obrazloženosti odluke, odnosno sumnje na arbitrarnost (primjerice U-III-7992/2014, U-III-5792/2011, U-III-1122/2013) ${ }^{85}$.

Kao što je već navedeno, članak 91a. ZPP-a Ustavni sud, na apstraktnoj razini, nije ocijenio neustavnim. Međutim, pogrešna primjena te odredbe na jedan konkretan slučaj dovela je do povrede prava na pristup sudu koju je utvrdio ESLJP. ${ }^{86}$ Presuda ESLJP-a Omerović (br. 2) protiv Hrvatske dovela je i do djelomične promjene prakse Ustavnog suda. Naime, prema stajalištu Ustavnog suda, rješenje Vrhovnog suda kojim se odbacuje kao nedopuštena revizija jer ju je podnijela stranka osobno, a uz reviziju nije priložila izvornik ili presliku potvrde o položenom pravosudnom ispitu, niti se takva potvrda u izvorniku ili preslici nalazi u spisu predmeta, nije pojedinačni akt u smislu članka 62. stavka 1 . Ustavnog zakona protiv kojeg bi Ustavni sud bio nadležan pružiti ustavnosudsku zaštitu. ${ }^{87}$ Ustavni sud je, u skladu s tim svojim stajalištem, odbacio i ustavnu tužbu podnositelja Omerovića. Promjena prakse Ustavnog suda sastoji se u tome da ako podnositelj u ustavnoj tužbi navede dovoljno elementa iz kojih se može posumnjati u pravilnost utvrđenja Vrhovnog suda da nije ispunjena pretpostavka iz članka 91.a ZPP-a za podnošenje revizije, tada takvu ustavnu tužbu neće odbaciti zbog svoje nenadležnosti. ${ }^{88} \mathrm{U}$ predmetu U-III-1793/2014 ${ }^{89}$ Ustavni sud je usvojio ustavnu tužbu i ukinuo rješenje Vrhovnog suda o odbačaju revizije podnositeljice. Nije naime bilo sporno da je podnositeljica diplomirana pravnica bez položenog pravosudnog ispita, te da je osobno potpisala reviziju, no u samoj je reviziji navedeno da ju podnosi podnositeljica zastupana po punomoćnici M. V., odvjetnici u Splitu, koja je potpisala reviziju i na nju otisnula svoj štambilj. Iz obrazloženja osporenog rješenja Vrhovnog suda nije bilo razvidno na temelju kojih činjenica je u konkretnom slučaju Vrhovni sud utvrdio da reviziju nije podnijela odvjetnica, već isključivo podnositeljica osobno. Ustavni sud je zaključio "da načinom na koji je Vrhovni sud primijenio zakon u konkretnom slučaju nije postignuta svrha članka 91a. ZPP-a, pri čemu je povrijeđena sama bit prava podnositeljice na pristup revizijskom sudu".

85 Odluke broj: U-III-7992/2014 od 5. ožujka 2015., www.usud.hr, U-III-5792/2011 od 6. lipnja 2014., www.usud.hr, U-III-1122/2013 od 4. studenoga 2014., Narodne novine, br. 149/14 i www.usud.hr

86 V. presudu ESLJP-a Omerović (br. 2) protiv Hrvatske, op.cit.

87 Primjerice rješenje broj: U-III-177/2015 od 19. veljače 2015., www.usud.hr

88 V. odluke broj: U-III-62/2014 od 20. veljače 2014. i U-III-1793/2014 od 23. svibnja 2014., obje objavljene na www.usud.hr

89 Odluka broj: U-III-1793/2014 od 23. svibnja 2014., www.usud.hr 


\subsubsection{Odbačaj tužbe u upravnom sporu (ne radi se o "upravnom aktu” ili "upravnoj stvari”)}

Osim u navedenim slučajevima, povredu prava na pristup sudu Ustavni sud često će utvrditi i u slučajevima kada Visoki upravni sud Republike Hrvatske, odnosno upravni sudovi, odbace tužbe pogrešno ocijenivši da osporeni akt nije upravni akt, odnosno da nije riječ o upravnoj stvari. ${ }^{90}$ Detaljnije navodimo samo dva slučaja. U predmetima U-III-617/2006 i U-III-4374/200591 riječ je bila o istovrsnim slučajevima, u kojima je Povjerenstvo za utvrđivanje statusa hrvatskih branitelja djelatnicima Ministarstva pravosuđa iz sustava izvršenja sankcija odbilo zahtjev (“zamolbu”) podnositelja za utvrđivanje sudjelovanja u Domovinskom ratu, koju su tražili radi stjecanja statusa hrvatskog branitelja. Odlukom Ministarstva pravosuđa, uprave i lokalne samouprave odbijeni su podnositeljevi prigovori protiv tih odluka. Upravni sud Republike Hrvatske odbacio je tužbe podnositelja zauzevši stajalište da osporene odluke nisu upravni akti, odnosno da "Povjerenstvo nije državno tijelo koje u obavljanju javnih ovlasti rješava u upravnim stvarima, nego bi njegove odluke imale karakter dokaznih isprava koje bi se mogle upotrijebiti u postupku pred upravnim tijelom koja su zakonom ovlaštena izdavati potvrde o statusu hrvatskog branitelja, a to je temeljem odredbe stavka 3. članka 2. Zakona o pravima hrvatskih branitelja iz Domovinskog rata i članova njihovih obitelji ... Ministarstvo obrane, odnosno Ministarstvo unutarnjih poslova." Ustavni sud je to stajalište Upravnog suda ocijenio neprihvatljivim. Pošao je od činjenice da su Povjerenstvo zajednički osnovali ministar obrane i ministar pravosuđa, na temelju prijedloga ministra pravosuđa "za rješavanje statusa hrvatskih branitelja djelatnicima Ministarstva pravosuđa iz sustava izvršenja sankcija koji su od 30. svibnja 1990. do 30. lipnja 1996. godine sudjelovali u Domovinskom ratu"; ono je djelovalo u okviru Ministarstva pravosuđa; pravna sredstva protiv prvostupanjskih odluka Povjerenstva imala su sva obilježja žalbe u smislu mjerodavnih odredbi ZUP-a/91 o kojima je odlučivalo u drugom stupnju Ministarstvo pravosuđa, uprave i lokalne samouprave (danas Ministarstvo pravosuđa); Povjerenstvo je provodilo postupke u kojima je utvrđivalo pravno relevantne činjenice te je izdavalo "potvrdu radi ostvarivanja statusa hrvatskog branitelja i prava u svezi s tim statusom". Drugim riječima, Ustavni sud je utvrdio da je riječ o odlučivanju o pravima stranaka. Citirano stajalište Upravnog suda, prema ocjeni Ustavnog suda, implicira pravnu situaciju u kojoj bi se o pravima stranaka (u konkretnom slučaju, o pravu na ostvarivanje statusa hrvatskog branitelja iz Domovinskog rata određene skupine djelatnika Ministarstva pravosuđa) odlučivalo u postupcima u kojima nijedno nadležno tijelo ne bi donosilo upravni akt pa bi ti postupci načelno bili izuzeti iz kontrole zakonitosti u upravnom

90 Odluke Ustavnog suda u kojima je utvrdio povredu nekih drugih ustavnih prava, primjerice prava na sudsku kontrolu zakonitosti zajamčenu člankom 19. stavkom 2. Ustava ili jednakosti pred zakonom zajamčenu člankom 14. stavkom 2. Ustava, ne navodimo u ovom radu.

91 Odluka broj: U-III-617/2006 od 25. siječnja 2011., Narodne novine, br. 20/11 i www.usud.hr i odluka broj: U-III-4374/2005 od 25. siječnja 2011., Narodne novine, br. 18/11 i www.usud. $\mathrm{hr}$ 
sporu. Za Ustavni sud je takvo tumačenje neprihvatljivo jer bi time i sve stranke u navedenim postupcima ostale bez ikakve sudske zaštite, što je protivno temeljnim načelima na kojima je ustrojen ustavni poredak Republike Hrvatske.

U predmetu U-III-5471/201192 prvostupanjskim upravnim rješenjem bio je odbijen zahtjev podnositelja za stambeno zbrinjavanje njega i članova njegove obitelji izvan područja posebne državne skrbi uz obrazloženje da isti ne ispunjava propisane uvjete. Drugostupanjsko tijelo odbilo je žalbu podnositelja, a Upravni sud je tužbu podnositelja usvojio, poništio drugostupanjsko rješenje te odbacio žalbu podnositelja kao nedopuštenu, s obrazloženjem da je riječ o pitanju koje prema svojoj prirodi nema karakter upravne stvari. Analizirajući cilj i svrhu donošenja i provedbe akata Vlade vezanih uz osiguranje stambenog zbrinjavanja osoba koje nisu vlasnici stana ili kuće, a koje su živjele u stanovima u društvenom vlasništvu na područjima koja su izvan područja posebne državne skrbi, te sam postupak u vezi sa zahtjevom osoba koje su smatrale da im pripada pravo na stambeno zbrinjavanje izvan područja posebne državne skrbi, Ustavni sud je ocijenio da prvostupanjsko rješenje "predstavlja akt koji u materijalnom (supstancijalnom), sadržajnom smislu ima karakter pojedinačnog upravnog akta, budući da se njime rješava o određenom pravu podnositelja te se neposredno odražava na ostvarivanje tog prava". Stajalište je Ustavnog suda da bi protiv takvog akta morala biti osigurana sudska zaštita ("sudska kontrola zakonitosti pojedinačnih akata upravnih vlasti i tijela koja imaju javne ovlasti”) zajamčena Ustavom. Pristup Upravnog suda, koji je uskratio podnositelju sudsku zaštitu protiv prvostupanjskog rješenja, ne ulazeći u sadržaj istog i ne ispitujući utječe li njegov sadržaj odnosno njegova provedba na nečija prava i obveze, odnosno zadržavajući se samo na formalističkom utvrđenju da u konkretnom slučaju, polazeći od donositelja i formalnog naziva akta, nije riječ o upravnom aktu iz članka 6. stavka 2. ZUS-a/91, Ustavni sud je ocijenio "isuviše formalističkim, koji nema svoje racionalno opravdanje, a takav pristup izravno utječe na pravo podnositelja da neovisni i nepristrani sud odluči o njegovom pravu u "meritumu"." ${ }^{93}$ Osim ove, Ustavni sud usvojio je još 10-tak identičnih ustavnih tužbi.

92 Odluka broj: U-III-5471/2011 od 16. travnja 2015., Narodne novine, br. 59/15 i www.usud.hr

93 Osim toga, Ustavni sud utvrdio je da je podnositelj postupio sukladno uputi o pravnom lijeku navedenoj u prvostupanjskom rješenju. Zaključak Upravnog suda, kojim je odlučeno da se o zahtjevu za stambeno zbrinjavanje u provedbi Zaključka Vlade ne odlučuje u upravnom postupku, donesen je na sjednici Imovinsko-pravnog odjela Upravnog suda broj: 6-Su122/2011-2 8. veljače 2011., nakon podnošenja tužbe podnositelja Upravnom sudu. U tom smislu Ustavni sud podsjetio je na stajalište ESLJP-a izraženo u presudi Majski (br. 2) protiv Hrvatske (presuda, 19. srpnja 2011., zahtjev br. 16924/08): “70. ... Iako je istina da je navedena odluka Upravnog suda donesena oko dva mjeseca prije nego što je podnositelj zahtjeva podnio svoju tužbu istom sudu, Sud ne smatra da je podnositelj zahtjeva trebao biti svjestan te odluke i zanemariti izričitu uputu o pravnim sredstvima sadržanu u odluci Državnoodvjetničkog vijeća koju je pobijao. To zato što je u predmetima kao što je ovaj, u kojemu je pravno sredstvo o kojemu je riječ rezultat sudskog tumačenja, u pravilu potrebno šest mjeseci da takav razvoj sudske prakse dosegne dovoljni stupanj pravne sigurnosti prije nego što se može smatrati da je javnost djelotvorno svjesna domaće odluke koja je uspostavila pravno sredstvo i da su osobe kojih se to tiče sposobne i obvezne koristiti ga (...)" 
Ustavni sud usvojio je ustavne tužbe zbog povrede prava na pristup sudu i u sljedećim predmetima: a) U-III-6526/2012 94 : Upravni sud u Rijeci odbacio je tužbu podnositeljice podnesenu protiv odluke Višeg disciplinskog suda Hrvatske odvjetničke komore kojom je potvrđena prvostupanjska presuda kojom je podnositeljica proglašena krivom zbog počinjenja teže povrede dužnosti i ugleda odvjetništva te joj je izrečena disciplinska mjera ukora. Ustavni sud je utvrdio da odluke disciplinskih tijela Hrvatske odvjetničke komore imaju karakter pojedinačnih odluka javnopravnih tijela u smislu članka 12. ZUS-a/10, a samim time i upravnog akta.; b) U-III-3937/201195: Upravni sud Republike Hrvatske odbacio je tužbu podnositelja podnesenu protiv odluke Ministarstva mora, prometa i infrastrukture Republike Hrvatske o raspodjeli CEMT godišnjih dozvola za 2011. (za međunarodni prijevoz tereta). Podnositelj je bio nezadovoljan time što nije dobio tu dozvolu. Prema ocjeni Ustavnog suda Upravni sud nije svoje stajalište obrazložio "nijednom riječju”. Propustivši utvrditi povlači li stjecanje CEMT dozvole za sobom određena prava podnositelja (primarno ekonomska, dakle i imovinsku korist, kao i pravo na osobni razvitak u području djelatnosti kojom se podnositelj bavi), a uzimajući u obzir i ostale čimbenike poput donositelja akta, javnopravni režim stjecanja i raspodjele dozvola itd., Ustavni sud morao je utvrditi da nije jasno po kojim je osnovama Upravni sud ocijenio da u konkretnom slučaju nije riječ o upravnim aktima. Prema ocjeni Ustavnog suda riječ je o propustu koji izravno utječe na pravo podnositelja da neovisni i nepristran sud odluči o njegovom pravu "u meritumu".; c) U-III-1621/2002 ${ }^{96}$ : U upravnom sporu bio je osporen zaključak Općine V., kojim se prihvaća izvješće Komisije za izbor najpovoljnije ponude za izvođenje radova na održavanju objekata i uređaja javne rasvjete na području Općine V. u 2002. godini, te se u tu svrhu prihvaća ponuda tvrtke "M." iz O. Ustavni sud je utvrdio da Zakon o komunalnom gospodarstvu ${ }^{97}$ predviđa sudsku kontrolu odluka o izboru najpovoljnije ponude za obavljanje komunalne djelatnosti, pa je ocijenio da nisu mjerodavne odredbe ZUS-a/91 već odredbe Zakona o komunalnom gospodarstvu.

Izdvajamo i predmete u kojima Ustavni sud nije našao povrede prava na pristup sudu, odnosno potvrdio je stajalište Visokog upravnog (Upravnog) suda da osporeni akti nisu upravni akti: a) U-III-2368/2012 ${ }^{98}$ : Upravni spor bio je pokrenut protiv Odluke Državnog sudbenog vijeća o imenovanju predsjednika suda broj: UPI-IPS-58/11 od 24. studenoga 2011.; b) U-III-1802/201599: Upravni spor bio je pokrenut protiv rješenja Hrvatskog fonda za privatizaciju donesenog na temelju članka 42. Zakona o privatizaciji (Narodne novine, broj 21/96., 71/97. i 73/00.) i članka 171. ZUP-a/91, u kojem rješenju se navode nekretnine koje su procijenjene

94 Odluka broj: U-III-6526/2012 od 6. lipnja 2013., Narodne novine, br. 75/13 i www.usud.hr

95 Odluka broj: U-III-3937/2011 od 14. prosinca 2011., Narodne novine, br. 1/12 i www.usud.hr

96 Odluka broj: U-III-1621/2002 od 3. studenoga 2005., Narodne novine, br. 137/05 i www. usud.hr

97 Zakon o komunalnom gospodarstvu, Narodne novine, broj 36/95, 70/97 i 128/99

98 Odluka broj: U-III-2368/2012 od 6. veljače 2014., Narodne novine, br. 25/14 i www.usud.hr

99 Odluka broj: U-III-1802/2015 od 27. svibnja 2015., www.usud.hr 
u vrijednost društvenog kapitala (točka I. izreke), dok je točkom II. izreke određeno da se to rješenje izdaje na zahtjev stranke, a za potrebe upisa nekretnina u zemljišne knjige, odnosno polaganja u knjigu isprava; c) U-III-3359/2012 ${ }^{100}$ : U upravnom sporu osporavala se Odluka Fakultetskog vijeća S. f. u S. B., kojom je odbijen kao neosnovan zahtjev za zaštitu prava podnositeljice na Odluku Fakultetskog vijeća S. f. u S. B. kojom je na radno mjesto docenta za znanstveno područje Tehničkih znanosti, znanstveno polje strojarstvo, znanstvena grana proizvodno strojarstvo, na Zavodu za industrijsko inženjerstvo S. f. u S. B., u sastavu Sveučilišta Josipa Juraja Strossmayera u Osijeku, izabran dr. sc. T. G., docent u naslovom zvanju.; d) U-III-41742/2009101: U upravnom sporu osporavale su se Izmjene i dopune Odluke o izboru najpovoljnije ponude za prodaju poljoprivrednog zemljišta u vlasništvu Republike Hrvatske na području Općine V. L. koju je donijelo Općinsko vijeće Općine V. L.

\subsubsection{Nepravodobnost tužbe ili pravnog lijeka}

Odbačaj tužbe ili pravnog lijeka zbog pogrešno utvrđene nepravodobnosti još je jedan od propusta suda koji može za posljedicu imati utvrđenje povrede prava na pristup sudu. Ustavni sud će se u ovakvom slučaju upustiti u utvrđivanje činjenice, primjerice dana primitka akta u povodu kojeg se koristi pravno sredstvo, dana i načina predaje pismena pošti ili datuma u koji pada zadnji dan roka ${ }^{102}$.

Ocjena je Ustavnog suda, u predmetu broj U-III-1373/2002, ${ }^{103}$ da iz obrazloženja osporenog rješenja Upravnog suda nije bilo razvidno na temelju kojih dokaza je taj sud utvrdio da je dostava rješenja o prestanku službe izvršena određenog datuma. Naime, izvršivši uvid u presliku dostavnice koja prileži spisu, Ustavni sud nije mogao sa sigurnošću utvrditi radi li se o datumu primitka rješenja 8. (osmog) prosinca 1999. godine, ili 28. (dvadesetosmog) prosinca 1999. godine. To iz razloga što je datum primitka ispisan samo brojčano, ali ne i slovima. Osim toga, iz jednog dopisa MUP-a bilo je razvidno da je podnositelj, uz ostale djelatnike, primio "rješenje o umirovljenju (...) tek 28. prosinca 1999. godine, te su shodno navedenom radili u periodu od 6.12. - 31.12.1999. godine". Slično i u predmetu U-III-5134/2005 ${ }^{104}$, u kojem je Ustavni sud čak zatražio i dodatno očitovanje Ministarstva financija kako bi mogao na nesumnjiv način utvrditi točan dan kada je podnositelj primio drugostupanjsko rješenje, što je, prema ocjeni Ustavnog suda, bio dužan učiniti Upravni sud.

100 Odluka broj: U-III-3359/2012 od 8. travnja 2014., www.usud.hr

101 Odluka broj: U-III-41742/2009 od 18. prosinca 2014., www.usud.hr

102 O dvojbama u računanju rokova za pokretanje postupka vidi: Marko Babić i Eduard Kunštek, "Rok za pokretanje postupka - prijepor o njegovu računanju", Zbornik Pravnog fakulteta Sveučilišta u Rijeci v. 36, br. 1., Rijeka, 2015.

103 Odluka broj: U-III-1373/2002 od 24. svibnja 2006., www.usud.hr

104 Odluka broj: U-III-5134/2005 od 20. svibnja 2008., www.usud.hr 
U predmetu U-III-799/2005 ${ }^{105}$ Ustavni sud je utvrdio kada je podnositelj zaprimio prvostupanjsko rješenje Trgovačkog suda, kada je predao žalbu i način na koji je poslao žalbu (preporučenom pošiljkom) te zaključio, s obzirom na zakonsko pravilo da se dan predaje podneska preporučenom pošiljkom smatra danom predaje sudu kojem se podnosi, da je žalba Visokom trgovačkom sudu pravodobna. Nadalje, odlukom U-III-2342/2006 ${ }^{106}$ Ustavni sud je ukinuo rješenje Vrhovnog suda kojim je prihvaćena revizija tuženika, ukinute nižestupanjske presude i odbačena, kao nepravodobna, tužba podnositelja radi utvrđenja da ovrha nije dopuštena. Vrhovni sud je zauzeo stajalište da je sudski rok u kojem je podnositelj (u ovršnom postupku) upućen u parnicu prekluzivan, a podnositelj je nesporno tužbu podnio dva dana nakon proteka tog roka, ali prije okončanja ovršnog postupka. Ustavni sud detaljno je analizirao odredbe Ovršnog zakona, sudsku praksu i stručnu literaturu, koje se odnose na institut "pokretanja parnice ili drugog postupka radi proglašenja ovrhe nedopuštenom nakon proteka roka koji je sud odredio, sve do dovršetka postupka", budući da je bio predmet brojnih izmjena i dopuna u razdoblju od stupanja na snagu Ovršnog zakona 1996. do dana odlučivanja Ustavnog suda. Ustavni sud nije mogao s izvjesnošću ustvrditi je li u vrijeme kada je podnositelj upućen na parnicu, tada važeći Ovršni zakon ${ }^{107}$ dopuštao pokretanje parnice radi proglašenja ovrhe nedopuštenom nakon proteka roka koji je sud odredio, sve do dovršetka postupka. S obzirom na navedeno, a imajući u vidu težinu posljedica (tužba podnositelja radi proglašenja ovrhe nedopuštenom uopće nije ispitana pred sudom), kao i činjenicu da Ustavnom sudu nije poznata nijedna druga odluka Vrhovnog suda u kojoj bi izrazio stajalište da je raj rok prekluzivan, Ustavni sud je ocijenio da je Vrhovni sud bio dužan uvažiti sve nejasnoće i proturječnosti teksta Ovršnog zakona koji je primijenjen na konkretan slučaj. Ustavni sud je ocijenio da je osporeno rješenje Vrhovnog suda, "dovelo do prekomjernog ograničavanja ustavnog prava podnositelja na sud u smislu članka 29. stavka 1. Ustava i članka 6. stavka 1. Konvencije".

Ustavni sud je u predmetu U-III-675/2009 ${ }^{108}$ utvrdio da je na pitanje računanja roka za podnošenje tužbe za smetanje posjeda trebalo primijeniti pravilo određeno u ZPP-u, kad posljednji dan roka pada na državni praznik ili u nedjelju ili u neki drugi dan kada sud ne radi, rok istječe prvog narednog radnog dana. U konkretnom slučaju zadnji dan roka za podnošenje tužbe isticao je u nedjelju.

U predmetu U-III-745/2009 ${ }^{109}$ Ustavni sud utvrdio je povrede prava na pravično suđenje u nekoliko aspekata (pristup sudu, jednakost oružja), formalistički pristup, te "opću" nepravičnost postupka za podnositelja, koje su uzrokovane, većim dijelom, rješenjem Vrhovnog suda koji je odbacio kao nepravodobnu reviziju podnositelja. Pravomoćnom presudom utvrđeno je da su bez pravnog učinka prema

105 Odluka broj: U-III-799/2005 od 21. lipnja 2005., Narodne novine, br. 82/05 i www.usud.hr

106 Odluka broj: U-III-2342/2006 od 11. srpnja 2007., Narodne novine, br. 86/07 i www.usud.hr

107 Ovršni zakon, Narodne novine, broj 57/96, 29/99 i 42/00.

108 Odluka broj: U-III-675/2009 od 8. veljače 2012., www.usud.hr

109 Odluka broj: U-III-745/2009 od 1. travnja 2010., Narodne novine, br. 50/10 i www.usud.hr 
stečajnoj masi određeni kupoprodajni ugovori, a podnositelju (tuženiku) naloženo je vratiti u stečajnu masu imovinske koristi stečene temeljem tih ugovora. Podnositelj je izjavio reviziju, a Vrhovni sud je remisorno vratio predmet prvostupanjskom sudu jer nije bila utvrđena vrijednost predmeta spora. Prvostupanjski sud pozvao je tužitelja da naznači vrijednost predmeta spora, što je ovaj i učinio podneskom naznačivši vrijednost predmeta spora iznosom koji ne dopušta reviziju. Vrhovni sud je reviziju podnositelja odbacio zbog preniske vrijednosti predmeta spora. Nakon toga prvostupanjski sud dopustio je povrat u prijašnje stanje koje je tražio podnositelj zbog propusta suda da mu dostavi podnesak tužitelja i da mogućnost da se očituje o po tužitelju određenoj vrijednosti predmeta spora, ukinuo je ranije rješenje o vrijednosti predmeta spora te novim rješenjem utvrdio vrijednost predmeta spora iznosom koji izjavljenu reviziju podnositelja čini dopuštenom. Prvostupanjski sud dostavio je cjelokupni spis Vrhovnom sudu radi odlučivanja o reviziji, no Vrhovni sud je dopisom izvijestio prvostupanjski sud da je o reviziji podnositelja već odlučeno (ranijim rješenjem o odbačaju revizije) i da ne postoje uvjeti za ponovno odlučivanje po toj reviziji. Prvostupanjski sud ponovo je dostavio reviziju Vrhovnom sudu, koji ju je sad odbacio zbog nepravodobnosti. Ustavni sud je ocijenio "očitim previdom" Vrhovnog suda koji je podnesak podnositelja kojim je "podsjetio" na već ranije izjavljenu reviziju ocijenio "novom" nepravodobnom revizijom. Uz utvrđene navedene povrede članka 29. Ustava, Ustavni sud je zaključio i da formalistički pristup Vrhovnog suda, s obzirom na okolnosti konkretnog slučaja, "nije dopustiv".

Odlukom U-III-54060/2009110 Ustavni sud je ukinuo rješenje Upravnog suda Republike Hrvatske o odbačaju tužbe podnositelja koji je omaškom "(očito) kao (pravno) neuka osoba" tužbu predao nenadležnom općinskom sudu. Ustavni sud "zamjerio" je i službeniku općinskog suda koji je zaprimio njegovu tužbu što ga nije "upozorio na učinjeni propust i uputio ga što treba (u)raditi". Nadalje, u predmetu U-III-2956/2012 $2^{111}$ Visoki upravni sud je računao rok za podnošenje tužbe "isključivo od dana dostave rješenja samoj stranci u upravnom postupku, iako je ona u njemu imala punomoćnika". Prema ocjeni Ustavnog suda, Visoki upravni sud je "propustio utvrditi je li izvršena dostava drugostupanjskog rješenja podnositeljevom punomoćniku te, ako je, kada se to desilo". Slično je i u predmetu U-III-7011/2014 ${ }^{112}$ Upravni sud u Zagrebu odbacio tužbu na temelju pogrešno

110 Odluka broj: U-III-54060/2009 od 5. prosinca 2012. (Arhiv USRH)

111 Odluka broj: U-III-2956/2012 od 31. ožujka 2015., www.usud.hr

112 Odluka broj: U-III-7011/2014 17. srpnja 2015., www.usud.hr. Ovaj je predmet zanimljiv i zbog toga što je Ustavni sud meritorno ispitivao ustavnu tužbu samo s aspekta istaknute povrede prava na pristup sudu počinjene rješenjem Upravnog suda. Podnositelj, službenik Zagrebačke županije, u upravnom sporu osporavao je rješenje kojim je ocijenjen za 2013. ocjenom "ne zadovoljava". Prema praksi Ustavnog suda meritorne odluke o ocjenjivanju službenika nisu pojedinačni akti u povodu kojih bi Ustavni sud bio nadležan pružiti ustavnosudsku zaštitu. U rješenju broj: U-III-4139/2014 od 25. studenoga 2014., Narodne novine, br. 13/15, Ustavni sud je naveo: "Eventualne pogreške u postupku ocjenjivanja državnog službenika mogu se osporavati samo u ustavnoj tužbi podnesenoj u povodu rješenja 
utvrđenog datuma kada je podnositelj zaprimio rješenje koje osporava u upravnom sporu. Taj "propust Upravnog suda u Zagrebu kod računanja pravovremenosti tužbe u upravnom sporu takve naravi da je doveo do povrede same biti prava na sud".

Odlukom U-III-600/2008 ${ }^{113}$ Ustavni sud je odbio ustavnu tužbu podnesenu u povodu rješenja Upravnog suda Republike Hrvatske, koji je odbacio tužbu kao nepravodobnu zbog 15-godišnjeg "kašnjenja". Podnositelj je naime bio razriješen dužnosti zamjenika okružnog javnog tužioca u Okružnom javnom tužilaštvu Zadar odlukom koju je zaprimio 26. listopada 1992., a tužbu Upravnom sudu podnio je 7. veljače 2007. Što se tiče podnositeljevog navoda da mu sporna odluka nikad nije dostavljena, već samo obavijest o njezinom donošenju, Ustavni sud je ukazao na to da je "člankom 46. Zakona o javnom tužilaštvu ('Narodne novine' broj 17/77., 17/86., 27/89., 34/89. - pročišćeni tekst, 16/90. i 41/90.) propisano da se razriješeni javni tužitelji i zamjenici istih obavještavaju o razrješenju te da je ta obavijest u konkretnom slučaju po svom sadržaju ista samoj odluci koja je objavljena u 'Narodnim novinama' broj 69/92. od 22. listopada 1992. godine. To je podnositelju, s obzirom na struku te dužnost koju je obnašao, bilo ili je moralo biti poznato, a o tome ga je, uostalom, Sabor i obavijestio dopisom od 1. travnja 2003. godine, kojeg je podnositelj priložio uz ustavnu tužbu".

\section{ZAKLJUČNO}

U većini slučajeva opisanih u ovom radu Ustavni sud je ispitivao je li došlo do povrede prava na pristup sudu, no u nekim predmetima koji bi činjenično potpadali pod te podnaslove zadržao se na općoj pravičnosti postupka i/ili je ocjenjivao ustavnu tužbu kroz neke druge aspekte članka 29. odnosno kroz neka druga ustavna prava. Iz navedenih primjera vidljivo je "traženje" definicija sadržaja ovog aspekta prava na pravično suđenje. Zaključno izdvajamo stajalište Ustavnog suda da oblike zajamčenog "prava na sud" čini i pravo na pokretanje postupka pred sudom, i pravo na rješavanje spora od strane suda, kao i pravo na pristup sudu u ovršnim postupcima to jest pravo na provedbu sudskih odluka (odnosno drugih akata koji se prema unutarnjem pravu države provode sudskom ovrhom), a moguće je u oblike "prava na sud" uvrstiti i pravo na djelotvoran pravni lijek (članak 13. Konvencije), shvaćen također kao zahtjev koji se odnosi na prava i obveze građanske prirode. ${ }^{114}$ Izdvajamo i stajalište da način na koji se primjenjuje

o prestanku državne službe, ako bi rješenje o ocjenjivanju državnog službenika bila osnova tog prestanka. U takvoj bi se situaciji, naime, mogla otvoriti sumnja u mogući nezakoniti prestanak državne službe (radnopravnog odnosa), koji je odnos nesporno predmet zaštite pred Ustavnim sudom. U tim okvirima bi Ustavni sud ispitao i samo rješenje o ocjenjivanju državnog službenika jer bi o njegovoj valjanosti ovisila i ocjena Ustavnog suda o glavnoj stvari koju razmatra u takvom ustavnom sporu."

113 Odluka broj: U-III-600/2008 od 9. travnja 2010., Narodne novine, br. 60/10 i www.usud.hr

114 Vidi odluku br. U-III-539/2008 (Narodne novine broj 75/12 i www.usud.hr), u kojoj je Ustavni sud naveo: "Stoga, sama činjenica da je podnositeljica imala pravnu mogućnost 
članak 29. stavak 1. Ustava ovisi i o posebnim obilježjima sudskog postupka o kojemu je riječ. Naime, osim što se cjelokupni postupak u kojem se odlučuje o nečijem pravu ili obvezi mora sagledavati kao jedinstvena cjelina, važno mjesto u ispitivanju prihvatljivosti nametnutih ograničenja ustavnom pravu na pristup sudu zauzima i uloga pojedinog suda u domaćem pravnom poretku (presuda Sotiris, § 18.), odnosno posebna obilježja postupka o kojem je riječ, zbog čega je potrebno uvijek uzimati u obzir i ulogu koju viši sudovi imaju u tom postupku (presuda Běleš, § 62.). ${ }^{115}$ Ustavni sud pažljivo pristupa u svakom pojedinačnom predmetu i uzima u obzir konkretne okolnosti, te je npr. u predmetu U-III-3816/2013 odbio ustavnu tužbu. ${ }^{116}$ Razmatrajući sadržaj ustavne tužbe, Ustavni sud je utvrdio da u njoj nisu navedeni ozbiljni, relevantni i dostatni razlozi zbog kojih bi bio dužan utvrditi povredu prava na pristup sudu u konkretnom slučaju, a na to nije, prema zaključku Ustavnog suda, upućivao ni sam predmet spora o kojemu su nadležni sudovi odlučivali u dva stupnja sudske jurisdikcije. Također je jedno od utvrđenja u praksi Ustavnog suda da načelo prema kojemu mora postojati mogućnost obraćanja sucu pripada u općepriznata temeljna načela prava. Bilo bi nezamislivo da se u pravnom poretku utemeljenom na vladavini prava strankama priznaju mnogobrojna procesna jamstva u postupku koji je u tijeku, a da se pritom ne štiti ono što zapravo omogućuje korištenje tim jamstvima. To je pristup sudu. Prema stajalištu Ustavnog suda obilježja pravičnosti, javnosti i brzine sudskog postupka nemaju nikakvu vrijednost ako sudskog postupka uopće nema. ${ }^{117}$

Tumačenje sadržaja ustavnih prava, koje Ustavni sud čini kroz svoje odluke i rješenja, smatramo najznačajnijim doprinosom razvoju ustavnog sudovanja, što je kroz prikazane primjere jasno vidljivo i svakako će i u daljnjoj praksi Ustavnog suda biti značajno analizirati i pratiti stajališta Ustavnog suda. To se odnosi i na pravo na pravično suđenje u svim njegovim aspektima, kao i na druga ustavna prava i slobode koje jamči Ustav Republike Hrvatske.

podnošenja žalbe sudu ne dovodi nužno, sama po sebi, do ispunjenja pretpostavki koje proizlaze iz članka 29. stavka 1. Ustava i članka 6. Konvencije. I dalje ostaje da se utvrdi je li stupanj tog pristupa dostatan da stranci osigura "pravo na sud" sa stajališta načela vladavine prava u demokratskom društvu".

115 Vidi, op. cit., predmet br. U-III-4374/2005.

116 Odluka Ustavnog suda donesena je 29. travnja 2015. i objavljena na www. usud. hr. Ustavni sud je uzimajući u obzir okolnosti konkretnog slučaja primijetio da je presuda Općinskog suda u Vinkovcima, broj: P-1134/12-135 donesena 8. studenoga 2012., dakle nakon stupanja na snagu i primjene ZID-a ZPP/11. Slijedom toga je i članak 53. stavci 1. i 6. ZID-a ZPP/11 primjenjiv u konkretnom slučaju. Sudska praksa Vrhovnog suda u pitanju o kojemu je riječ, prema utvrđenju Ustavnog suda, čvrsta je, ustaljena i dosljedna. Ustavni sud je istaknuo da bi u okolnostima konkretnog slučaja došao do zaključka kako ona, kao takva, dovodi do povrede ustavnog prava podnositeljica potrebni su ozbiljni, relevantni i dostatni razlozi koji bi bili sadržani u ustavnoj tužbi i koji bi mogli uvjeriti Ustavni sud da su jači od "prava" koje se dosljedno primjenjuje na sve ostale istovrsne ili slične slučajeve.

117 Odluka i rješenje br. U-III-5765/2012, U-III-5797/2012, U-III-5804/2012 od 11. ožujka 2014., objavljeni su u Narodnim novinama, br. 41/14 i na www.usud.hr 


\section{Summary}

\section{THE RIGHT OF ACCESS TO A COURT AS AN ASPECT OF THE RIGHT TO A FAIR TRIAL}

The topic of this paper is the right of access to a court, as an aspect of the right to a fair trial guaranteed by Article 29 of the Constitution and Article 6 of the Convention. The paper highlights the fundamental significance of the protection offered by the Convention, which concerns the drawing up and implementation of standards for the protection of human rights within the territory of Europe, and, through the positions of the European Court of Human Rights, which the Constitutional Court of the Republic of Croatia has accepted and elaborated in its adjudication. The paper also emphasises the importance of the Constitutional Court's activism concerning the protection of human rights. It stresses the view that the purpose of Article 29 of the Constitution and of Article 6 of the Convention is to secure fair proceedings, and not to examine the correct outcome of proceedings. The authors prove this thesis in this paper. The basic theme of the paper, the right of access to a court, is recognised by the authors as the key aspect of the constitutional right to a fair trial. The first part of the paper deals in general with the right to a fair trial and its various aspects, it provides an overview of the case law of the European Court of Human Rights and of its effect on the case law of the Constitutional Court in its specific aspects, and provides the standpoints of other States. This is followed by a detailed analysis of the positions of the Constitutional Court with regard to the right of access to a court and, in particular, the evolution of these positions over time in this area of protection. The positions of the Constitutional Court are presented both through an abstract and an individual review of constitutionality. The interpretation of constitutional rights, which the Constitutional Court provides through its decisions and rulings, is considered by the authors to be the most significant contribution to the development of constitutional adjudication in the Republic of Croatia.

Keywords: Constitutional Court, fair trial, access to a court, European Court of Human Rights, the Convention, the Constitution. 


\section{Zusammenfassung}

\section{DAS RECHT AUF GERICHTSZUGANG ALS ASPEKT DES RECHTS AUF FAIRES VERFAHREN}

Ausgehend vom Gerichtszugang als Aspekt des Rechts auf ein im Artikel 29 der Verfassung und Artikel 6 der EMRK gewährleistetes faires Verfahren, behandelt die vorliegende Arbeit die Hauptbedeutung des Konventionsschutzes, nämlich Schaffung und Anwendung des Schutzstandards für Menschenrechte innerhalb Europa, sowie durch die Stellungnahmen des Europäischen Gerichtshofs für Menschenrechte. Die genannten Stellungnahmen hat das Verfassungsgericht der Republik Kroatien angenommen und anhand konkreter Rechtsfälle weiter ausgearbeitet, was sein verfassungsgerichtlichen Aktivismus im Bereich der Menschenrechte ausprägt. Dabei wird betont, der Zweck von Artikel 29 der Verfassung und Artikel 6 der EMRK sei die Gewährleistung eines fairen Verfahrens und nicht Überprüfung der Richtigkeit von Verfahrensergebnissen. Die Autoren betrachten das Recht auf Gerichtszugang durch die Lupe des Verfassungsrechts auf faires Verfahren. Erstens wird in generellen Zügen das Recht auf faires Verfahren dargestellt; danach wird ein Blick in die Rechtsprechung des Europäischen Gerichtshofs für Menschenrechte geworfen, und anschließend daran ihr Einfluss auf die Rechtsprechung des Verfassungsgerichts erläutert. Stellungnahmen von anderen Staaten in dieser Hinsicht werden auch analysiert. Zugleich werden die Stellungnahmen des Verfassungsgerichts in Bezug auf die abstrakte und individuelle Aufsicht der Verfassungsmäßigkeit veranschaulicht. Auflegung des Verfassungsrechtsinhalts, welcher sich aus der Stellungnahmen und Lösungen des Verfassungsgerichts ergibt wird von den Autoren als der wichtigste Beitrag zur Entwicklung der kroatischen Verfassungsjudikatur herausgehoben.

Schlüsselwörter: Verfassungsgericht, faires Verfahren, Gerichtszugang, Europäischer Gerichtshof für Menschenrechte, EMRK, Verfassung. 


\section{Riassunto}

\section{IL DIRITTO ALL'ACCESSO ALLA GIUSTIZIA QUALE ASPETTO DEL DIRITTO AL GIUSTO PROCESSO}

Il tema del contributo è l'accesso alla giustizia, quale aspetto del diritto ad un giusto processo garantito dall'articolo 29 della Costituzione e dall'articolo 6 della Convenzione europea per la salvaguardia dei diritti e delle libertà fondamentali. Nel contributo si sottolinea il significato di fondo della protezione dettata dalla Convenzione, la quale consiste nella creazione e nell'utilizzo di standard di protezione dei diritti umani nella cornice dello spazio giuridico dell'Europa. Ancora, attraverso gli orientamenti della Corte europea dei diritti dell'uomo, accolti e approfonditi dalla Corte costituzionale della Repubblica di Croazia, si segnala il significato dell'attivismo costituzionalistico nella tutela dei diritti dell'uomo. Si pone in rilievo l'orientamento secondo il quale lo scopo dell'art. 29 della Costituzione, come anche dell'art. 6 della Convenzione vada ricercato nella garanzia del giusto processo, anziché nella verifica della validità dell'esiti della procedura. Gli autori dimostrano tale tesi mediante il presente lavoro. L'interesse di base di questo contributo, il diritto all'accesso alla giustizia, viene riconosciuto dagli autori alla stregua di un aspetto fondamentale del diritto costituzionale al giusto processo. Nella prima parte del lavoro s'accede all'indagine del diritto al giusto processo in generale ed ai suoi aspetti; ancora, si passa in rassegna la prassi della Corte europea dei diritti dell'uomo, come pure la sua influenza sulla giurisprudenza della Corte costituzionale nell'aspetto concreto, menzionando gli orientamenti stranieri. Nel prosieguo del lavoro si analizzano nel dettaglio gli orientamenti della Corte costituzionale collegata al diritto di accesso alla giustizia ed in particolare l'evoluzione degli orientamenti in tale ambito. Gli orientamenti della Corte costituzionale vengono illustrati dagli autori in maniera astratta e mediante un controllo individuale di legittimità costituzionale. L'interpretazione del contenuto dei diritto costituzionali, offerta dalla Corte costituzionale attraverso le sue sentenze ed i provvedimenti, è considerato dagli autori come il contributo più significativo nell'intero processo di sviluppo della giustizia costituzionale nella Repubblica di Croazia.

Parole chiave: Corte costituzionale, giusto processo, accesso alla giustizia, Corte europea per i diritti dell'uomo, Convenzione europea per la salvaguardia dei diritti e delle libertà fondamentali, Costituzione. 